\title{
KOMUNISTISKĀ ĒTIKA \\ KĀ NOMENKLATŪRAS UZVEDĪBAS KONTROLES INSTRUMENTS LATVIJAS KOMUNISTISKĀS PARTIJAS POLITIKĀ \\ $(1944-1982)^{\star}$
}

\section{Daina Bleiere}

Dr. hist., Latvijas Universitātes Latvijas vēstures institūta vadošā pētniece. Pētnieciskās intereses: Latvijas 20. gadsimta vēsture, padomju režīma ietekme uz Latvijas sabiedrību.

Raksts veltīts Latvijas historiogrāfijā līdz šim maz pētītam jautājumam - partijas kontroles un sodu sistēmai un tās pielietošanai nomenklatūras uzvedības regulēšanā. Balstoties uz Latvijas Komunistiskās partijas institūciju arhīviem, rakstā analizēti partijas ētikas pamatprincipi, sodi un kontrolējošās institūcijas, kā arī sodīšanas politikas attīstība saistībā ar tādiem partijas ètikas normu pārkāpumiem kā šķiriskās modrības zaudēšana, dienesta stāvokḷa izmantošana un sadzīves morāles pārkāpumi.

Atslēgas vārdi: partijas ētika, nomenklatūra, partijas kontrole, šķiriskuma princips, dienesta stāvokḷa izmantošana, sadzìves morāle.

\section{PROBLĒMAS IZPĒTES PAKĀPE UN AVOTI}

Raksta mērḳis ir parādīt, kā darbojās un evolucionēja kompartijas sodu un institūciju sistēma, apkarojot nomenklatūras darbinieku veiktos t.s. partijas ètikas normu pārkāpumus Latvijā 1944.1982. gadā. Hronologiski raksts aptver laika posmu no padomju režīma atjaunošanas Latvijā 1944./45. gadā līdz 1982. gadam. 1983. gadā uzsāktās skaḷās korupcijas lietas (piemēram, t.s. Uzbekijas kokvilnas lieta) ieguva plašu rezonansi, un jautājums par nomen-

* Raksts izstrādāts projekta "Latvijas teritorija kā dažādu kultūrtelpu, religiju, politisko, sociālo un ekonomisko interešu saskarsmes zona no aizvēstures līdz mūsdienām" ietvaros. 
klatūras privilēgijām un l̦aunprātībām perestroikas laikā kḷuva par vienu no sabiedrības opozīciju padomju sistēmai mobilizējošiem faktoriem. Lìdz ar to mainījās principi, pēc kuriem notika kadru atlase un vērtēšana. Rakstā izskatītajā laika posmā partijas institūcijas neizjuta sabiedriskās domas tiešu spiedienu, tās orientējās pēc vadlīnijām, kuras noteica partijas augstākā vadība Maskavā, tādēl izmaiṇas disciplinārlietu politikā (ja tādas bija) labāk parāda kompartijas un padomju kadru politikas evolūciju.

Par izpētes objektu ir izvēlētas amatpersonas, kas ietilpa Latvijas Komunistiskās partijas (LKP) Centrālās komitejas (CK), rajonu (līdz 1950. gadam - apriņķu) un pilsētu komiteju nomenklatūrās. Iespēju robežās rakstā lielāka uzmanība pievērsta LKP CK nomenklatūrai, jo attieksme pret augstākā līmeṇa partijas amatpersonām būtỉbā ir kopējās sodu politikas indikators.

Lai gan nomenklatūra un tās funkcionēšana Padomju Savienībā tiek visai intensīvi pētīta, jautājumam, kā/un vai tika mēǵināts panākt tās atbilstību noteiktiem ètiskiem standartiem, nav pievērsta pietiekama uzmanība. Termina "nomenklatūra" popularizācijā liela loma bija Mihaila Vosḷenska tāda paša nosaukuma grāmatai, ${ }^{1}$ taču pilnīgi pamatoti ir norādīts, ka "autors nesniedz vairāk faktiskās informācijas par personāla atlasi un izbrāķēšanu". ${ }^{2}$ Morāles problēmām un to saistībai ar partijas disciplināro politiku ir veltītas Edvarda Kona (Edward D. Kohn) un Šîlas Ficpatrikas (Sheila Fitzpatrick) publikācijas. ${ }^{3}$ Tajās netiek īpaši izdalīti partijas un pārvaldes institūciju funkcionāri kā pētījuma mērkşa grupa. Tomēr jāṇem vērā, ka pastāvēja būtiskas atšķirības ierindas partijas biedru un nomenklatūras uzvedībā un arī partijas ètikas principu pielietošanā viņu sodīšanā. Piemēram, atskaite par 1971.-1973. gadu liecina, ka 70. gadu pirmajā pusē visiem komunistiem kopumā tipiskākais sodīšanas iemesls bija sadzīves morāles un uzvedības pārkāpumi, bet nomenklatūrai - nolaidība vai neveiksmes darba pienākumu veikšanā, nevis ètiskas dabas pārkāpumi. ${ }^{4}$ Šajā laika posmā bija sodīti 34 atbildīgie darbinieki, kas ietilpa LKP CK nomenklatūrā, no tiem 16 par nepietiekamu pakḷauto institūciju kontroli un četri par trūkumiem darbā ar kadriem. Partijas rajonu un pilsētu komitejas atbildīgajiem darbiniekiem, kas ietilpa šo komiteju nomenklatūrā, bija uzlikti 848 sodi, no tiem 483 par nepietiekamu kontroli pār padotajiem. ${ }^{5}$ Faktiski partijas sodi bija sava veida piedeva daudziem 
amatiem, jo vadītājiem bija jāatbild par institūcijas darbu arī tad, ja sodu bija izraisījuši apstāḳ̣i, kas bija ārpus viṇu kontroles.

Saistību starp nomenklatūras ètiku un sodu sistēmu ir pētījuši daži krievu vēsturnieki, diemžēl pārsvarā pievēršoties laika posmam pirms Otrā pasaules kara. ${ }^{6}$ Pēckara laikam veltīti vairāki referāti, kas publicēti Maskavā 2015. gadā izdotajā rakstu krājumā. ${ }^{7}$ Tajos tiek izvirzīti vairāki būtiski jautājumi - par partijas kontroles institūciju attīstību, kadru mobilitāti, korporatīvās disciplīnas pasākumiem. Latvijas kompartijas politika komunistu un it sevišķi nomenklatūras ētikas normu uzturēšanā līdz šim nav pētīta, lai gan šie jautājumi ir atspoguḷoti dokumentu krājumos ${ }^{8}$ un tiem ir pieskārušies autori citos pētnieciskajos kontekstos. ${ }^{9}$

N̦emot vērā raksta ierobežoto apjomu un to, ka sodu politikas ìstenošanu rajonu un pilsētu līmenī kontrolēja $\mathrm{LKP}^{10} \mathrm{CK}$, raksts pārsvarā balstās uz tās arhīva fondu materiāliem. Tie ir LKP CK PA-101. fonds, LKP CK nomenklatūras personāllietu fonds (PA-15500) un LKP CK Partijas kolēgijas/komisijas/kontroles komisijas (tālāk - Partijas komisija vai PK) fonds (PA-2160). Pirmie divi l̦auj iegūt informāciju par partijas disciplinēšanas politiku attiecīgajā laika periodā - kongresu, plēnumu un CK biroja lēmumos, kā arī par komunistu sodīšanas praksi, izskatot konkrētas personāllietas CK birojā vai sekretariātā. CK birojam bija jāizskata visi zemākstāvošo komiteju lēmumi par izslēgšanu no partijas biedru vai kandidātu vidus, atjaunošanu partijā un partijas stāža pārtraukumiem, sodīto apelācijas par citu institūciju uzliktajiem partijas sodiem, kā arī CK biroja agrāk uzlikto sodu atcelšana. Birojs arī pieṇēma lēmumus par LKP CK nomenklatūras darbinieku sodīšanu, kā arī izskatīja Padomju Savienības Komunistiskās partijas $\left(\mathrm{PSKP}^{11}\right)$ CK Partijas kontroles komitejas (PKK) darbinieku ziņojumus, kas bija tapuši, izskatot tajā iesniegtās sūdzības no Latvijas vai arī plānveidīgi izskatot konkrētu pārkāpumu izplatību. Partijas komisijas fondā līdz 70. gadiem ir atrodamas tikai izskatītās personāllietas un VK(b)P/PSKP CK Partijas kontroles komisijas lēmumi gadījumos, kad sodītās personas bija iesniegušas lūgumus par apelāciju. Pilnīgāka dokumentācija (sarakste ar PSKP CK PKK, statistika par LKP CK un rajonu un pilsētu partijas komiteju praksi komunistu disciplinārlietās u.c. materiāli) ir pieejama tikai par 70. un 80. gadiem. Būtisks trūkums ir tas, ka trūkst PK sēžu protokolu, lai 
gan sēžu stenogrammas ir pievienotas atsevišķām personāllietām. Dažkārt disciplinārlietu būtību palīdz noskaidrot partijas pirmorganizāciju vai komiteju sanāksmju protokoli. Atsevišksos gadījumos informācija tika meklēta arī Rīgas pilsētas partijas komitejas (PA-102. fonds) un rajonu komiteju fondos. Noderīgs avots ir arī bijušo nomenklatūras darbinieku atmiņas un publikācijas presē.

\section{PARTIJAS ĒTIKAS PAMATPRINCIPI UN PARTIJAS SODI}

Padomju Savienības Komunistiskās partijas biedru un it sevišķi tās augstākā slāņa - partijas nomenklatūras ètikas normu definēšana sākās jau 20. gados, kad tika izdoti vairāki lēmumi un publikācijas, kas izskaidroja partijas biedriem vēlamās uzvedības normas. ${ }^{12}$ Šajā laikā tika formulēti minimālie standarti, kas bija kopēji visiem partijas biedriem, bet it īpaši nomenklatūrai. Pamatprincips, kas bija definēts t.s. partijas ètikas diskusijas laikā 20. gados, noteica, ka nav universālas (vispārcilvēciskas) ētikas, tā ir šķiriska, tādēḷ "pareizi, ètiski, labi ir tas, kas palīdz ìstenot mūsu mērḳi, kas palīdz sagraut mūsu šķiras ienaidniekus, iemācīties saimniekot uz sociālistiskiem pamatiem; nepareizs, neētisks, nepiel̦aujams tas, kas tam kaitē. No šāda skatpunkta jāaplūko ikviena partijas biedra rīcība, ja mēs gribam atbildēt uz jautājumu, vai tā ir ētiska vai nē." ${ }^{13}$ Respektīvi, dienesta stāvokḷa izmantošana, dzeršana vai nekārtīga dzimumdzīve ir neētiska rīcība nevis pati par sevi, bet gan tādēl, ka tā traucē lielā mērḳa - komunistiskās sabiedrības sasniegšanu, un funkcionāra rīcība bija jāvērtē no tā viedokḷa, cik stipri tā kaitēja partijas politikai.

Šķiriskuma princips noteica, ka komunistam jāpiesargās nonākt šķiriski svešu elementu ietekmē. Tas ietvēra gimeniskas attiecības vai draudzēšanos ar cilvēkiem, kas tika uzskatīti par naidīgiem padomju varai, tāpat arī atrašanos nekomunistiskajās partijās un organizācijās, kā arī piesliešanos "nepareizajiem” grupējumiem, piemēram, trockistiem pašā partijā, utt. Lìdz 1939. gadam cilvēki, kas vēlējās iestāties partijā, tika sadalīti vairākās grupās. Visvieglākie iestāšanās noteikumi bija proletāriskas izcelsmes kandidātiem, vissarežg̀ìtākie - tiem, kas nāca no "ekspluatatoru” šķirām. Pēc šā 
noteikuma atcelšanas šḳiriskā izcelsme joprojām bija svarīga, gan iestājoties partijā, gan arī ikvienā nomenklatūras karjeras posmā. Ikvienam potenciālajam kompartijas biedram bija jāizpilda kadru anketa, kurā bija jānorāda visi tuvākie radinieki (vecāki, brāli, māsas, sieva/vīrs, bērni), bet autobiogrāfijā bija jāapraksta savs dzīves gājums, norādot savu sociālo izcelšanos, vecāku nodarbošanos un sociālo stāvokli, tuvāko radinieku nodarbošanos un dzīvesvietu, kā arī kompromitējošus faktus par viņiem vai arī pat tālākiem radiniekiem (tēvočiem, tantēm, brālēniem un māsīcām). Piemēram, Latvijā biežāk sastopamie kompromitējošie fakti pēckara gados bija vecāku vai radinieku darbība neatkarīgās Latvijas vai vācu okupācijas laikā (piederība pie politiskajām partijām, dienēšana vācu armijā u.c.) vai arī atrašanās emigrācijā.

Komunistu uzvedības kontrolei tika izveidoti noteikti institucionāli mehānismi un sodu sistēma. Disciplinēšanas sistēma bija vertikāli no apakšas uz augšu būvēta, respektīvi, uzvedības pārkāpumus vispirms izskatīja tā partijas pirmorganizācija, kurai piederēja attiecīgais partijas biedrs. Pirmorganizācijas lēmumu par soda nepieciešamību un lielumu apstiprināja augstākstāvošā partijas komiteja (rajona un/vai pilsētas), kas varēja atcelt pirmorganizācijas ieteikto sodu vai arī to pastiprināt. Gadījumos, kad sods bija izslēgšana no partijas, galīgo lēmumu pieņēma LKP CK birojs vai sekretariāts sadarbībā ar LKP CK Partijas kolēǵiju/komisiju/kontroles komiteju. Birojs vai sekretariāts izskatīja arī komunistu apelācijas par rajona vai pilsētas komiteju noteiktajiem sodiem. Tā 1980. gadā CK birojs izskatijja 19 apelācijas par izslēgšanu no partijas. Deviṇos gadījumos izslēgšanu atcēla un nomainīja uz stingro rājienu ar ierakstu uzskaites kartītē. ${ }^{14}$ Gadījumos, kad sodāmā persona piederēja PSKP CK nomenklatūrai, galīgo lēmumu varēja pieņemt tikai PSKP CK PKK. Tā arī izskatīja apelācijas par zemāka līmeņa partijas orgānu noteiktajiem sodiem - izslēgšanu vai stingro rājienu. Tāda pati kārtība pastāvēja uzlikto sodu anulēšanā.

Partijas statūtos, kas bija pieņemti 1934. gadā un papildināti 1939. gadā, partijas sodi individuāliem partijas biedriem nebija konkretizēti, ja neskaita izslēgšanu no partijas. Tie paredzēja "vienu vai otru nosodījuma veidu (aizrādījumu, rājienu u.tml.), publisku nosodījumu, pagaidu atstādināšanu no atbildīga partijas un padomju darba, izslēgšanu no partijas, izslēgšanu no partijas ar pazi- 
ņošanu par pārkāpumu administratīvām un tiesu iestādēm". ${ }^{15}$ Vēl nekonkrētāk šis jautājums bija formulēts 1952. gadā pieṇemtajos statūtos, lai gan tajos bija ierakstìts iepriekš neminēts soda veids partijas biedru pārcelšana kandidātos uz laiku līdz vienam gadam. ${ }^{16}$ Faktiski bija izveidojusies noteikta sodu sistēma un to hierarhija: izteikt piezīmi (ukazat'), brīdināt (preduprezhdat'), aizrādīt (postavit' na vid), izteikt rājienu, izteikt rājienu ar ierakstu uzskaites kartītē, izteikt rājienu ar brīdinājumu un ierakstu kartītē, izteikt stingro rājienu, izteikt stingro rājienu ar ierakstu uzskaites kartītē, izteikt stingro rājienu ar ierakstu uzskaites kartītē un brīdinājumu (par to, ka pārkāpuma atkārtošanās izraisīs izslēgšanu), izslēgt. 1962. gadā pieņemtajos statūtos pirmo reizi sodi bija rakstiski uzskaitīit pēc stingrības pakāpes: brīdinājums, rājiens bez ieraksta partijas uzskaites kartītē, rājiens ar ierakstu, stingrais rājiens bez ieraksta, stingrais rājiens ar ierakstu, izslēgšana no partijas. ${ }^{17}$ Tika saglabāta arī pārcelšana kandidāta statusā uz laiku, šo normu atcēla 1966. gadā.

Bargākais jeb "augstākais partijas soda mērs" - izslēgšana no partijas - nomenklatūras darbiniekam automātiski gandrīz vienmēr nozīmēja arī atcelšanu no ieņemamā amata un karjeras beigas, parasti arì visu agrāko sasniegumu, apbalvojumu un privilēǵiju anulēšanu. No partijas automātiski izslēdza arī tos, pret kuriem bija uzsākta kriminālvajāšana, jo komunists principā nevarēja atrasties ieslodzījumā. Retajos gadijumos, kad tiesa apsūdzēto attaisnoja vai arī viņš saṇēma nosacìtu sodu, viṇu atjaunoja partijā, taču dokumentos tika norādīts pārtraukums partijas stāžā, kuru savukārt varēja noṇemt pēc kāda laika par labu uzvedību. Tomēr dokumentos fiksēti gadījumi, kad amatpersonām bija izdevies izkḷūt cauri visiem filtriem un notiesāšanas gadījumā par dienesta stāvokḷa l̦aunprātīgu izmantošanu saglabāt partijas biedra statusu un nepārtrauktu partijas stāžu. ${ }^{18}$

Tiesības izslēgt no partijas cilvēkus, kas bija jebkura līmeṇa partijas komiteju (rajona, republikas CK un tās biroja, PSKP CK) locekḷi vai kandidāti, pēc statūtiem bija tikai tam partijas orgānam, kura loceklis bija attiecīgais komunists, nevis vina partijas pirmorganizācijai. Tā republikas CK locekḷus un kandidātus, kā arī Revīzijas komisijas locekḷus varēja izslēgt šo organizāciju plēnums. Faktiski plēnumi apstiprināja iepriekš pieņemtos CK biroja vai 
sekretariāta lēmumus. Attiecīgi rajona vai pilsētas komitejas locekl̦us izslēdza šo komiteju biroji un pēc tam apstiprināja plēnumi. Bez izslēgšanas bija arī vieglāki sodi, piemēram, pārcelšana no balsstiesīga komitejas locekḷa par kandidātu (t.i., bez balsstiesībām). Izslēgtajiem bija tiesības iesniegt apelāciju attiecīga vai augstāka lìmeña partijas komisijai, LKP CK biroja lēmumus varēja apstrīdēt PSKP CK PKK, bet tā gandrīz vienmēr piekrita LKP CK biroja lēmumiem par izslēgšanu. Apelācijas augstākstāvošajiem orgāniem varēja iesniegt par jebkuru partijas sodu, tomēr parasti apelācijas bija par izslēgšanu un par stingro rājienu ar ierakstu uzskaites kartìtē. Jāatzīmē, ka stingrais rājiens ar ierakstu bija l’oti nopietns sods, kuru parasti piesprieda vai nu par atkārtotiem, vai arī par smagiem pārkāpumiem. Bieži (bet ne vienmēr) tas tika papildināts ar atcelšanu no amata. Taču šajā gadījumā funkcionārs netika izdzīts no nomenklatūras un, lai gan parasti tika iecelts zemāka ranga amatā, saglabājās cerība pēc kāda laika zaudēto stāvokli atgūt.

Visai tipisku partijas darbinieka karjeras līkloču ainu parāda Eduarda Beišāna gadījums. Vitebskā dzimušais E. Beišāns 1942.1945. gadā bija dienējis 130. latviešu strēlnieku divīzijā. Pēc demobilizācijas virsnieka pakāpē viņš strādāja par instruktoru LK(b)P CK, 1948. gadā kḷuva par Ogres apriņķa pirmo sekretāru, 1950. gadā apbalvots ar Darba Sarkanā Karoga ordeni, bet 1951. gadā ievēlēts par LPSR Augstākās padomes (AP) deputātu. 1952. gada maija beigās VK(b)P CK viṇu apstiprināja par Daugavpils apgabala komitejas Administratīvās nodaļas vadītāju. Taču mēnesi vēlāk - 21. jūnijā Beišānu Rīgā aizturēja milicija kopā ar Ogres rajona Staļina kolhoza priekšsēēetāju Vaḷikovu. Abi esot bijuši piedzērušies, bet Beišāns atteicies uzrādìt dokumentus, atsaucoties uz AP deputāta statusa neaizskaramību. LK(b)P CK birojs 19. augustā atcēla vinu no amata un izteica stingro rājienu. Sods tika pamatots ar to, ka, vadot Ogres rajonu, Beišāns esot piẹ̦āvis kolhozu īpašuma izlaupī̌šnu un kolhozu kadru "piesārṇotību”. Dzeršana un necienīga uzvedība tika pieminētas kā papildus apsūdzības. ${ }^{19} \mathrm{CK}$ jau iepriekš bijis zināms par tieksmi uz dzeršanu, bet acīmredzot E. Beišānam ir bijis pamats uzskatìt, ka CK pret viṇu izturas labi, lai gan 1951. gada aprīlī birojs bija viṇam izteicis rājienu par rupjību. ${ }^{20}$ Kā teica CK otrais sekretārs F. Titovs, Beišānam "pietrūka idejiskuma, partijiskas degsmes". ${ }^{21}$ Interesanti, ka stingro rājienu 
viṇam atcēla jau 1952. gada decembrī, ${ }^{22}$ iespējams, tādēl, lai viṇš varētu strādāt 43. latviešu strēlnieku divīzijas politiskajā daḷā par vecāko instruktoru.

1955. gada novembrī E. Beišāna pārtrūkusī karjera atkal uzņēma apgriezienus - viņu iecēla par Limbažu rajona pirmo sekretāru. 1958. gada janvārī viņu ievēlēja par LKP CK locekḷa kandidātu, februārī apbalvoja ar otru Darba Sarkanā Karoga ordeni par rajona panākumiem lauksaimniecībā. Tomēr jau drīz vien no Limbažiem ienāca sūdzības par E. Beišāna uzvedību. Lietas izmeklēšanas rezultātā CK birojs 8. jūlijā vinuu atbrīvoja no darba un izteica stingro rājienu ar ierakstu uzskaites kartītē "par neapmierinošu rajona vadību, par iedzeršanām ar vairākiem rajona darbiniekiem, par radu būšanu un neuzstājību darbā ar kadriem". ${ }^{23}$ Lai gan CK nozìmēja E. Beišānu darbā uz Balvu rajona izpildkomiteju un viņam kā nomenklatūras darbiniekam bija jāpakḷaujas CK rīkojumam, viņam izdevās izvairīties no darba provincē un kḷūt par LPSR Tirdzniecības ministrijas kantora "Latbakaleja" Tirdzniecības nodaḷas vadītāja vietnieku un pat par "Latbakalejas" partijas organizācijas sekretāru. ${ }^{24}$ Tā kā E. Beišānu bija sodīis CK birojs, sodu varēja atcelt tikai šajā līmenī, taču process, atšķirībā no iepriekšējiem gadījumiem, kad viņš bija CK nomenklatūras darbinieks, bija jāiziet no pašas apakšas. "Latbakalejas" partijas pirmorganizācijas lēmums par soda atcelšanu bija jāapstiprina Rīgas pilsētas Kirova rajona komitejai, savukārt tās lēmumu apstiprināja Rīgas pilsētas partijas komiteja. Pēc tam lieta nonāca LKP CK, kur vispirms Partijas komisija to izskatīja un rekomendēja sodu atcelt, ko birojs izdarīja 1959. gada 20. oktobrī. ${ }^{25}$

Jāatzīmē, ka partijas sodu atcelšana parasti notika no pusgada līdz divu gadu laikā, lai gan bija gadījumi, kad kaut kādu iemeslu dēḷ sodus neatcēla daudz ilgāk (nav labojies, mainījis darbavietas utt.). Tā Rīgas pilsētas Kirova rajonā, pēc 1980. gada 1. janvāra datiem, sodi bija uzlikti 175 komunistiem, 122 - ar ierakstu uzskaites kartītē, 53 - bez ieraksta; 13 komunistiem partijas sodi ilga vairāk nekā piecus gadus, bet deviņiem vienlaicīgi bija divi sodi. ${ }^{26}$ 


\section{KONTROLES INSTITŪCIJU LOMA PARTIJAS DISCIPLINNAS UZTURĒ ŠANĀ}

Augstākajā līmenī institūciju, kuras uzdevums bija uzraudzìt, kā komunisti ievēro partijas disciplīnu, līdz 1952. gadam sauca par Partijas kontroles komisiju, bet pēc tam - par PSKP CK Partijas kontroles komiteju. 1962.-1965. gadā to apvienoja ar PSRS Ministru padomes (MP) Valsts kontroles komiteju. Pēc N,ikitas Hruščova atcelšanas no amata partijas kontroli atkal atdalīja no valsts kontroles. Izņemot 1962.-1965. gada posmu, PKK ievēlēja partijas kongresos. Formāli PKK bija augsts statuss, pārsvarā tās vadìtāji bija Politbiroja locekḷi. PKK uzdevums bija pārbaudīt partijas disciplīnas ievērošanu, sodīt vainīgos komunistus, izskatīt apelācijas par izslēgšanu. PKK varēja sūdzēties arī par dažādām partijas biedru piel̦autām nelikumībām un pārkāpumiem.

Atbilstošām institūcijām bija jāpastāv arī republiku/apgabalu/ novadu un rajonu/pilsētu partijas komiteju līmenī, bet ar katru līmeni to statuss pazeminājās. Atbilstoši PSKP statūtiem republikas līmenī Partijas komisiju, atškịīibā no Revīzijas komisijas, neievēlēja kongresā, tās vadītāju iecēla CK birojs, bet apstiprināja pirmais plēnums pēc kārtējā kongresa, tāpat kā CK nodaḷu vadītājus.

1940. gada 29. decembrī Latvijas Komunistiskās (bolšseviku) partijas Centrālās komitejas birojs nolēma pie Orginstruktoru nodaļas izveidot apelācijas grupu partijas biedru lietu izskatīšanai. ${ }^{27}$ Partijas kolēgiju nodibināja 1943. gada 31. decembrī. Par tās sekretāru (vadītāju) 1944. gada martā iecēla Kārli Gaili. ${ }^{28}$ Par pirmajiem Partijas kolēgijas locekḷiem kḷuva Moisejs Aršs ${ }^{29}$ (1944. gada aprīlī) un tieši gadu vēlāk - Alīda Sīkstule. ${ }^{30}$ Viṇiem bija divi palīgi (instruktori). Vēlāk štatu sarakstos bija paredzēts tikai viena instruktora amats. 1947. gada martā notika rokāde - Augstākās padomes Prezidija priekšsēdētāja vietnieks Pēteris Plēsums ${ }^{31}$ un K. Gailis apmainījās amatiem. ${ }^{32}$ 1953. gada janvārī kolēgiju likvidēja, bet pusgadu vēlāk - jūnijā izveidoja Partijas komisiju, P. Plēsums kḷuva par tās priekšsēdētāju. Viņš atradās šajā amatā līdz 1960. gada maijam, kad viṇu nomainīja Roberts K̦īsis. ${ }^{33}$ 1973.-1985. gadā šo amatu pildīja Pjotrs Ribal̦čenko, ${ }^{34}$ bet 1985.-1990. gadā - Stepans Paljora. ${ }^{35}$ 1986. gada maijā Partijas komisiju pārdēvēja par Partijas kontroles komisiju. 
PK uzdevums bija gatavot materiālus CK biroja sēdēm saistībā ar apelācijām par izslēgšanu un partijas sodu atcelšanu, kā arī uzturèt kontaktus ar PSKP CK PKK un pēc tās pieprasījuma sniegt informāciju. Jāatzīmē, ka laikā, kad PKK vadīja Arvīds Pelše (19661983), tā arvien vairāk saplūda ar valsts kontroli, pārņemot tās funkcijas. Tas atspoguḷojās arī Latvijas Partijas komisijas darbā, tā izskatīja ne tikai disciplinārlietas, bet arī sūdzības par dzīvokḷu piešķiršanu, darba strīdus u.tml., turklāt komisijai bija jāgatavo pārskati par atsevišķu nozaru darbu un pat par to, kāpēc uzṇēmumi nepilda savas saistības, piemēram, kāpēc Rīgas vagonu rūpnīca nav piegādājusi Dienvidslāvijai elektrovilcienus. ${ }^{36}$

1973.-1976. gadā Partijas komisija bija piedalījusies 25 CK birojā izskatīto jautājumu sagatavošanā. Septiṇos gadījumos tās bija personāllietas par 10 atbildīgiem darbiniekiem par ļaunprātīgu dienesta stāvokḷa izmantošanu, četros gadỉjumos par l̦aunprātībām kolektīvās dārzkopības un vasarnīcu kooperatīvu jomā, vienā gadījumā par pārmērībām banketu rīkošanā. 17 gadījumos materiālus gatavoja komisija viena pati, bet aston,os - kopā ar CK nodal̦ām vai Tautas kontroles komiteju. ${ }^{37}$ Kopā ar CK nodaḷām tika gatavoti jautājumi, kas attiecās uz noteiktu nozari vai tās pārstāvjiem. Tāpat arī komisijas sagatavotie materiāli tika nosūtīti zemākstāvošajām partijas komitejām personāllietu izskatīšanai.

Vismaz kopš 50. gadu beigām Partijas komisijā iekḷāva arī ārštata locekḷus, pārsvarā nopelniem bagātus vecos komunistus, piemēram, vismaz kopš 1958. gada komisijā bija iekḷauta Marta Krustiņsone. ${ }^{38}$ Arī P. Plēsums pēc PK priekšsēdētāja amata atstāšanas un došanās pensijā darbojās kā komisijas ārštata loceklis. Pirmais oficiālais ārštata locekḷu saraksts ir pieejams no 1963. gada janvāra. Tajā bija pieci personālie pensionāri, divi strādnieki un Baltijas kara apgabala Partijas komisijas sekretārs. ${ }^{39}$ 1974. gadā PK bija četri štata un 10 ārštata locekḷi. ${ }^{40}$

Partijas komisijas pastāvēja arī pie pilsētu un rajonu partijas komitejām, kā arī pie partijas komitejām ar rajona komitejas tiesībām. Sākumā tās darbojās sabiedriskā kārtā, t.i., priekšsēdētāju pienākumus pildīja kāds no attiecīgās komitejas štata darbiniekiem, bet locekḷi tika pieaicināti acīmredzot pēc tiem pašiem principiem kā LKP CK PK. Septiṇdesmitajos gados daḷā partijas komiteju 
priekšsēdētāji tika atalgoti. 1975. gadā no 43 pilsētu un rajonu komitejām un iestāžu un organizāciju partijas komitejām ar rajona komitejas tiesībām 22 bija algoti partijas komisiju priekšsēdētāji. ${ }^{41}$

\section{PARTIJAS ĒTIKAS NORMAS UN SODİŠANAS PRAKSE 1944.-1982. GADĀ}

Salīdzinot ar partijas un saimnieciskās disciplīnas pārkāpumiem (t.i., partijas institūciju lēmumu un darba pienākumu pienācīgu nepildīšanu), nomenklatūras darbinieki par ētikas pārkāpumiem tika sodīti samērā reti. 1948. gadā no 41 sodìtā LKP CK nomenklatūras darbinieka partijas ètikas pārkāpumi bija astoṇos gadijumos. ${ }^{42}$ 1971.-1973. gadā no 36 sodītajiem LKP CK nomenklatūras darbiniekiem seši bija sodīti par dienesta stāvokḷa izmantošanu un nelikumīgām darbībām personīga labuma gūšanai, tikpat daudz par necienīgu uzvedību un viens par biogrāfijas datu slēpšanu. Šajā pašā laika posmā no sodītajiem 848 rajonu un pilsētu partijas komiteju nomenklatūras darbiniekiem 84 bija sodīti par morāli sadzīviskiem pārkāpumiem un 13 par kukuļṇemšanu. Aptuveni tāda pati proporcija ir vērojama atsevišķos rajonos. Būtu pārsteidzīgi uzskatīt, ka sodīto skaits var kalpot, lai mērītu nomenklatūras morālo kvalitāti katrā atsevišķā rajonā vai republikā kopumā. Šie dati drīzāk atspoguḷo attiecīgā rajona vadības darba stilu un sodu politiku.

Jāatzīmē, ka ètiskas dabas pārkāpumi bieži vien tika samiksēti kopā ar citiem pārkāpumiem, kas varēja notikt vai nu tāpēc, ka attiecīgā amatpersona bija ne tikai nekompetenta, bet arī korumpèta un amorāla, vai arī aiz apzinātas vēlēšanās parādīt pārkāpēju kā morāli degradējušos cilvēku. Pēdējā pieeja tika izmantota, piemēram, gadījumos, kad funkcionārs aizbēga uz ārzemēm. Tā 1979. gada jūlijā Itālijā politisko patvērumu lūdza Jūrmalas pilsētas komjaunatnes komitejas pirmais sekretārs Sergejs Zamaščikovs, kas tur bija ieradies ar tūristu grupu. LKP CK biroja lēmumā par šo gadījumu bija uzsvērts, ka pārbēdzējs esot bijis "idejiski un morāli sapuvis cilvēks bez stingriem morāliem principiem”. ${ }^{43}$

Nacionālkomunistu “tīrīšanu” laikā 1959.-1962. gadā apsūdzības nacionālismā tika papildinātas un pastiprinātas ar biogrāfijas 
datu slēpšanu. Piemēram, "Cīṇas” redaktoram Pāvilam Pizānam inkriminēja, ka, stājoties partijā, ir slēpis, ka vācu okupācijas laikā divas reizes ir bijis aizturēts un pēc tam atbrīvots. ${ }^{44}$ Komjaunatnes pirmo sekretāru Vladislavu Ruskuli apsūdzēja par to, ka, stājoties partijā, viņš nebija norādījis, ka viens no viṇa tēva brāļiem vācu laikā bijis policists un 1945. gadā notiesāts uz 15 gadiem, arī viens no mātes brāḷiem bijis policists un kara beigās devies uz ārzemēm, savukārt mātes māsa ar vīru bija aizbēgusi uz Zviedriju. Kompromitējošas ziņas it kā bijušas arī par citiem onkuḷiem. Sods šajā gadījumā bija atcelšana no amata un stingrais rājiens ar ierakstu. V. Ruskuli nosūtīja strādāt par Bauskas rajona izpildkomitejas priekšsēdētāja vietnieku, bet 1963. gada februārī atbrīvoja arī no šā amata, kā pamatojumu atkal izvirzot biogrāfijas datu slēpšanu. ${ }^{45}$ Traipi biogrāfijā tika meklēti, arī cenšoties atrast pamatojumu CK Lauksaimniecības nodạ̧as vadītāja Antona Lūriṇa atcelšanai no amata. ${ }^{46}$ Kompromitējošus materiālus (par darbību sociāldemokrātos līdz 1934. gadam) mēǵināja atrast arī par Valsts plāna priekšsēdētāja vietnieku Edgaru Mūkinu. ${ }^{47}$

Lai gan teorētiski, stājoties partijā vai arī saņemot paaugstinājumu amatā, pretendentam pietika uzrādīt savā autobiogrāfijā (dzīves aprakstā) un anketā viṇu kompromitējošu informāciju, tomēr bija vairāki apstākḷi, kas veicināja informācijas slēpšanu. Pirmkārt, nekad nevarēja droši zināt, vai kompromitējošie fakti tiks piedoti. Otrkārt, dažkārt to koncentrācija bija tik liela, ka visu uzrādīšana karjeru sagrautu tūlīt. Tādēḷ apzināti vai neapzināti biogrāfijas nereti tika redigèetas, iekḷaujot ne visu kompromitējošo informāciju vai arī pasniedzot to nevainīgāk. Dažkārt cilvēku biogrāfiju līkloči bija pārsteidzoši. Piemēram, 1972. gadā no partijas izslēdza kāda kolhoza priekšsēdētāju A.Z., jo, stājoties partijā, esot noslēpis, ka neatkarīgās Latvijas laikā bijis Zemnieku savienības biedrs, bet vēl pirms tam - skautu instruktors. A.Z. bija izsūtīts no Latvijas 1949. gada 25. martā. Izsūtījumā Tomskas apgabalā strādājis par cūkkopi un viṇa darbs bijis tik izcils, ka viņš apbalvots ar trīs Vissavienības Tautas saimniecības sasniegumu izstādes medaḷām, daudziem goda rakstiem un medaḷu "Par pašaizliedzīgu darbu". Tur arī viņam piedāvāts iestāties partijā. Izpildot anketu, viņš norādījis, ka 1944.-1945. gadā dienējis vācu armijā un ka 1933.-1940. gadā bijis aizsargs, bet nav norādījis jau pieminētās ziṇas un to, ka vācu 
okupācijas laikā bijis aktīvs “Tēvijas sargu” dalībnieks. 1961. gadā A.Z. atgriezies Latvijā, strādājis par zootehniḳi sovhozā, bet jau pēc pusgada bija izvirzìts par kolhoza priekšsēdētāju. ${ }^{48}$

Lauksaimniecības speciālisti visu aplūkoto laika posmu bija viena no apdraudētākajām grupām no "šķiriskās modrības" un kadru politiskās uzticamības viedokḷa. Tā kā kvalificētu lauksaimniecíbas kadru un partijas biedru bija l,oti maz, rajonu komitejas 40.-50. gados ḷoti bieži visai pielaidīgi skatījās uz energisku un perspektīvu speciālistu biogrāfijām un izcelsmi. To labi ilustrē sovhoza "Madliena" ilggadējā direktora Jūlija Beḷavnieka biogrāfija. Viņš bija cēlies no "kulaku" gimenes. Lai iestātos Bulduru dārzkopības tehnikumā, viņš anketā tēvam piederējušās zemes platību bija samazinājis (27, nevis 57 ha), bet par tēva dalību aizsargu organizācijā bija noklusējis. Tehnikumā J. Bel̦avnieks bija uzņemts komjaunatnē, taču neilgi pirms beigšanas 1952. gadā tehnikuma vadība bija atklājusi faktu sagrozišanu un panākusi viņa izslēgšanu no komjaunatnes, kas automātiski nozīmēja arī teicamnieka atestāta nepiešķiršanu un zaudētu iespēju uzreiz iestāties Lauksaimniecības akadēmijā. Viņš neizmantoja obligātajā karadienestā 1955. gadā piedāvāto iespēju iestāties partijā. Jauns piedāvājums sekoja 1958. gadā, kad J. Beḷavnieks jau strādāja "Madlienā". "Daudz netielējos, jo sapratu - agri vai vēlu nāksies piekrist. [..] Pēteri Saliņu [sovhoza partijas organizācijas sekretāru. - D. B.] uzreiz informēju par nepatikšanām, kādas vecāku biogrāfijas dẹl savulaik jau nācās piedzīvot komjaunatnē. Pēteris gan to lietu pavērsa tā: tev taču jāmin fakti par sevi, nevis par tēvu! Tāpēc iesniegtajos dokumentos norādīju, ka esmu dzimis zemnieku gimenē, nekonkretizējot zemes platību." 49 Tomēr 1967. gadā, kad J. Bel̦avnieku gribēja iecelt par Ogres rajona izpildkomitejas priekšsēdētāju, biogrāfijas datu dēl kandidatūra tika noraidīta. "Lai gan savulaik iesniegtajā biogrāfijā es neko nebiju melojis, tomēr nācās rakstīt paskaidrojumus rajona partijas komitejai. Par dažu biogrāfisku datu noklusēšanu mani kolēgi - biroja locekḷi - izteica mutisku rājienu, šķiet, pēc nākamās rajona konferences neievēlēja arī biroja sastāvā. Protams, arī nākamajās Augstākās Padomes vēlēšanās par deputāta kandidātu vairs netiku virzīts." 50

1970. gadā līdzīgu nodarījumu atklāja J. Beḷavnieka bijušajam padotajam, tolaik Ogres dārzkopības izmēginājumu stacijas direktoram Albertam Gasonam, kurš, stājoties partijā, 1957. gadā bija 
norādījis, ka tēvs 1945. gadā bijis izsūtīts un drīz vien pēc tam miris, lai gan patiesībā Kara tribunāls viṇu bija notiesājis uz 18 gadiem. A. Gasons apgalvoja, ka nav to zinājis, bet sods bija stingrais rājiens. ${ }^{51}$

Atsevišķu rajonu partijas komiteju un CK politika 60. un 70. gados biogrāfijas datu slēpšanas jautājumā varēja būtiski atšḳirties, atkarībā no lietas apstākḷiem, no tā, vai runa bija par vecāku vai paša funkcionāra biogrāfiju, kā arī atkarībā no apsūdzētās personas reputācijas. Piemēram, 1971. gada jūnijā Rīgas pilsētas L̦eņina rajona (tag. Zemgales priekšpilsēta) partijas komitejas birojs sodīja ar stingro rājienu ar ierakstu kādas mācību iestādes vadītāju par to, ka esot noslēpis, ka viṇa tēvs bijis aizsargs, bet pats savā laikā esot aizbēdzis no izsūtījuma vietas. Jau 1972. gada aprīlī sodu atcēla, jo sodītais "savu nepatiesīgumu partijas priekšā ir nosodījis. Prasmīgs vadìtājs un aktīvs PSKP biedrs. Ievēlēts par partijas biroja locekli." ${ }^{2}$

Jāuzsver tomēr, ka ne tikai lauksaimniecības speciālistiem, bet visiem, kas savu nomenklatūras karjeru sāka pēc Staļina nāves, apstākḷi bija labvēlīgāki nekā tiem, kas to mēgināja darìt līdz 1953. gadam. Tad izslēgšana no partijas un amata zaudēšana par biogrāfijas datu slēpšanu bija gandrīz vai garantēta, tajā skaitā arī laukos. Šajā laikā arī būtiska apsūdzība bija sakari ar "škiras ienaidniekiem", ar ko visbiežāk tika saprasta sievas un vīra izcelšanās un biogrāfija, viṇu radinieki utt. L,oti bieži šādas apsūdzības balstījās uz baumām un pieṇēmumiem un tika izvirzìtas, lai panāktu apsūdzamās personas bargāku sodīšanu. Nereti iemesli varēja būt personiskas dabas - sadzìves konflikti, greizsirdība. Tā 1949. gada 26. jūnijā Valkas apriņ̧̧a partijas komitejas birojs izskatīja apriņ̧̧a prokurora Jāṇa Lūša (Lūsa) lietu un atzina, ka viņš par šoferi esot pieṇēmis izsūtīta kulaka dēlu, bet viṇa sekretāre - mašīnrakstītāja esot tā paša kulaka radiniece, turklāt viṇas brālis dienējis vācu armijā. Lūsim vēl tika pārmesta "saimnieciska apaugšana", dienesta stāvokḷa l̦aunprātīga izmantošana, kā arī "politiska tuvredzība". ${ }^{3}$ Lietas attīstībā zināma loma bija viṇa sievas greizsirdības izraisītajām sūdzībām, kuras gan viṇa vēlāk bija atsaukusi, tomēr LPSR Prokuratūra vairumu apriņ̧̧̧a komitejas izvirzìto apsūdzỉbu atzina par pamatotām. ${ }^{54}$ Neviens funkcionārs tajā laikā nevarēja izvairīties no šāda veida saskares ar "tautas ienaidniekiem", tādēḷ sodīšana ḷoti bieži sakrita ar kārtējo modrības kampaṇu. 
Daudz retāki bija gadījumi, kad cilvēki, kas ieṇēma kādus amatus, apzināti uzturēja sakarus ar represētajiem. Viens no tiem bija Alūksnes apriņķa Kalnienas mežniecības iecirkņa priekšnieka Antona Sluča lieta. CK Partijas komisija atbalstīja 1949. gada 25. jūlijā pieņemto Alūksnes apriņ̧̧a partijas komitejas lēmumu izslēgt viṇu no partijas kandidātiem. A. Sluči milicija bija aizturējusi Tomskā, jo viṇš izsūtījuma vietā bija apciemojis savu 25. martā izsūtīto sievu, kā arī nodevis naudu un mantas trijām izsūtìto gimenēm citās izsūtījuma vietās un paṇēmis 97 vēstules un septiṇas atklātnes, lai izsūtītu tās adresātiem Latvijā. ${ }^{55}$

Lai gan problēmas ar biogrāfiju pieskaņošanu padomju varas prasībām bija pārsvarā vietējās izcelsmes funkcionāriem, taču no tām nebija pasargāti arī no citām republikām atsūtītie nomenklatūras darbinieki, kaut gan visumā viņi tika uzskatīti par uzticamākiem. L,oti daudzi latviešu izcelsmes funkcionāri 1937.-1938. gada represijās bija zaudējuši vecākus un citus tuvus radiniekus. Tas nebija šḳēerslis karjerai, ja atspoguḷojās anketās un autobiogrāfijās. Svarīgi bija arī norādīt, ka funkcionārs neuztur nekādus kontaktus ar represētajiem, neko nezina par viņu likteni pēc aresta. Dažkārt arī nenorādī̌̌ana neradīja nopietnas sekas. Tā 1951. gada martā Baškīrijā dzimušais Arnolds Zandmanis rakstija paskaidrojuma vēstuli LKP CK pirmajam sekretāram Jānim Kalnbērziņam, kurā skaidroja, ka, lai gan anketā neesot norādījis, ka viṇa brālis Jūlijs 1937. gadā arestēts un 1940. gadā ieslodzījumā miris, taču par šo faktu zinājuši valsts drošības ministrs Alfons Noviks un Partijas kolēgijas priekšsēdētājs Pēteris Plēsums. Viṇu nesodīja, tieši otrādi, jūlijā CK birojs apstiprināja A. Zandmani par Rīgas pilsētas Kirova rajona komitejas pirmo sekretāru. ${ }^{56}$ Manipulācijas ar biogrāfijas datiem bija bieži sastopamas, bet gadījumos, kad bija "nepareizā" sociālā izcelsme, tās bija neizbēgamas. Tā 1947. gadā CK saṇēma drošîbas iestāžu informāciju, ka Krievijā, Omskas apgabalā, dzimušais Rīgas pilsētas L,eņina rajona izpildkomitejas priekšsēdētāja vietnieks Pēteris Kaṇepīts esot cēlies no kulaka gimenes, kurai 1927. gadā ir bijušas atņemtas vēlēšanu tiesības (t.s. lishentsy), un viņš to nav norādījis savās anketās. CK Kadru dạ̧a uzdeva L,eņina rajona komitejai nekavējoties atcelt Kaṇepīti no amata un izskatìt lietu pa partijas linniju. ${ }^{57}$

Rezumējot var teikt, ka šḳiriskuma principā visskaidrāk izpaudās komunistiskās ētikas nesavienojamība ar tradicionālajām ētikas 
normām, tās amoralitāte. Kā ierindas komunisti, tā arī funkcionāri tika nostādīti situācijā, kurā viṇiem bija jāizvēlas starp gimeni, radiniekiem, draugiem un karjeru. Turklāt partijas ètika bija liekulīga, jo augsta ranga funkcionāriem nevēlama izcelšanās vai gimenes locekḷu biogrāfijas netraucēja karjerā, kā tas bija turīga zemnieka dēlam Arvīdam Pelšem, kura brālis bija emigrējis uz ASV (A. Pelše gan konsekventi apgalvoja, ka jau kopš 1915. gada neuztur sakarus ar gimeni).

L̦aunprātīga dienesta stāvokḷa izmantošana viskroplīgākajās formās izpaudās kara laikā 1944./45. gadā un pirmajos pēckara gados, kad nomenklatūras amatus lielā skaitā aizpildīja Maskavas atsūtītie kadri, kā arī uz vietas demobilizētie virsnieki. Daudzi no viņiem uzlūkoja Latviju kā iekarotu un naidīgu teritoriju, kurā var īpaši nerēḳināties ar vispārpieņemtajām normām, it sevišḳi provincē, kur kontrolējošās instances bija tālu. Dzeršana, atklātas un slēptas laupīšanas, vardarbība šajā laikā bija l̦oti bieži sastopama, un šajā ziṇā īpaši izcēlās iznīcinātāju bataljonu kaujinieki, miliči, Valsts drošības tautas komisariāta (VDTK, kopš 1946. gada - Valsts drošîbas ministrija - VDM) darbinieki, nereti arī pagastu un ciemu padomju izpildkomiteju vadītāji, pagastu partorgi. Samērā tipiska parādība apriņ̧̧u līmenī bija sava veida vietējo augstāko amatpersonu "kooperatīvi", kas izmantoja pārvaldītās teritorijas resursus sava dzives līmeņa uzlabošanai. 1946. gada maijā CK birojs izskatīja l̦aunprātības Viḷakas apriņ̣̂ī, kur dažādu resursu (pārtikas produktu, rūpniecības preču) nelikumīgā sadalē bija iesaistīta gandrīz visa apriņ̧̧̧a vadība. 1946. gada novembrī tika izskatīti līdzīgi nodarījumi Aizputes apriṇķī. Raksturīgi, ka abos gadījumos apriņķa partijas pirmie sekretāri izspruka no soda, jo acīmredzot tika uzskatīts, ka viṇi pietiekami sekmīgi pilda savu galveno uzdevumu labības un citu produktu nodošanu valstij. ${ }^{58}$

Protams, ne vienmēr amatpersonām izdevās izvairīties no soda. 1952. gada 5. augustā CK birojs izskatìja l̦aunprātības Grīvas rajonā, kur visa rajona priekšniecība bija izsaimniekojusi Kirova kolhoza resursus un, pilnīgi iespējams, arī citu kolhozu mantu. Viṇi arī labprāt bija piedalijjušies iedzeršanās, kuras bija rīkojis kolhoza priekšsēdētājs Timpers. Kad Timperu notiesāja par kolhoza mantas izsaimniekošanu uz 15 gadiem, bet priekšniecība nepalīizēja, viṇš uzrakstīja sūdzību, kas, iespējams, nebūtu ieguvusi tik lielu 
rezonansi, ja tieši tajā laikā nebūtu notikusi kampaņa pret lauksaimniecības artel̦u statūtu pārkāpējiem. Tomēr arī liaunprātību mērogi tika uzskatīti par ārkārtējiem, jo, kā sēdē izteicās Daugavpils apgabala komitejas sekretārs Nikolajs Bisenieks, "tas ir vien̄̄gais gadījums, kad visi sekretāri, visi biroja locekḷi [rajona komitejas. - D. B.] tādā vai citādā ziṇā ir sevi sasmērējuši”. ${ }^{59}$ Sākumā Daugavpils apgabala komisijas sankcijas skāra tikai divas amatpersonas - rajona izpildkomitejas priekšsēdētāju V. L,ešinu un viņa vietnieku M. L,ebedevu, kuriem tika izteikti stingrie rājieni ar ierakstu un brīdinājumu. ${ }^{60}$ Tomēr CK veiktās izmeklēšanas rezultātā partijas komitejas sekretāru Andrjuhinu atbrīvoja no amata un izslēdza no partijas, sekretāru Agafonovu, VDM rajona nodaļas vadītāju Jekimovski un Laucesas MTS politnodaḷas vadītāju Surkovu CK birojs nolēma atbrīvot no amata un uzlikt stingro rājienu ar ierakstu, kā arī uzdeva republikas prokuroram izpētìt sīkāk viņu darbību. ${ }^{61}$ Sods Andrjuhinam bija netipiski bargs, iespējams, to ietekmēja viṇa agrākā darbība Ilūkstes un Ludzas apriṇķu partijas komitejas sekretāra amatā. ${ }^{62}$

Pēckara gados dienesta stāvokḷa l̦aunprātīga izmantošana neaprobežojās ar vidējo un zemāko līmeni, tā zēla arī republikas kompartijas CK un citu vadošo institūciju atbildīgo amatpersonu vidū, turklāt izpaudās ne tikai kā valsts resursu izmantošana, bet arī vietējo iedzīvotāju mantas (pārsvarā mēbel̦u, trauku, dažādu citu mantu) piesavināšanās. Gandrīz visi gadījumi, kad pirmajos pēckara gados republikas augstākie partijas funkcionāri tika sodīti ar izslēgšanu no partijas un kriminālvajāšanu, attiecās uz šādiem nodarījumiem. Visai raksturīga bija Vasīlija Kušteiko rīcība Liepājas pilsētas partijas komitejas kadru sekretāra amatā 1945. gadā. Viņš bija piesavinājies mēbeles no bezsaimnieku dzìvokḷiem, uz kara laiku konfiscètos radioaparātus, mantas no pilsētas partijas komitejas seifa, to skaitā Liepājas aizsargu pulka ceḷojošo balvu, kristāla vāzes, galda piederumus, traukus u.c. ${ }^{63} \mathrm{~V}$. Kušteiko paaugstināja amatā par LK(b)P CK Transporta nodaḷas vadītāja vietnieku, bet sūdzības par viņa darbību Liepājā izraisīja kriminālvajāšanu. 1946. gada 5. septembrī vinuu izslēdza no partijas VK(b)P CK Partijas kontroles komisija (jo viņš piederēja Maskavas nomenklatūrai). Tomēr kriminālais sods acīmredzot nebija pārāk bargs, jo jau 1948. gada martā LK(b)P CK lūdza viṇu atjaunot partijā, ko gan PKK noraidīja. ${ }^{64}$ 
VK(b)P CK PKK 1946. gada septembrī izslēdza no partijas LK(b)P CK finanšu saimniecības sektora vadītāja vietnieku Arkādiju Puhovicki, ${ }^{65}$ mēnesi vēlāk par līdzīgu nodarījumu LK(b)P CK birojs nolēma atbrīvot no amata un izslēgt no partijas bijušo CK Transporta nodaļas vadītāja vietnieku Aleksandru Leppiku, tobrīd Rīgas tabakas fabrikas direktoru. ${ }^{66}$ Tika sodīti vēl vairāki CK darbinieki. 1947. gada 17. februārī LK(b)P CK birojs ar stingro rājienu ar ierakstu sodīja MP priekšsēdētāja vietnieku Jevgeņiju Roni, viṇu arī atcēla no amata. Šajā gadījumā iemesls bija vairākas denunciācijas. Viena no tām bija adresēta VK(b)P CK sekretāram Andrejam Ždanovam un attiecās uz J. Roṇa pusmāsu J. Medvedevu, kuru viņš bija iekārtojis par sovhoza "Lorupe" direktori un kura esot pārvērtusi saimniecību par sava brāḷa "personīgo palīgsaimniecību", bet pēc atmaskošanas viņš esot palīdzējis māsai aizbēgt. Otru sūdzību bija izraisījis konflikts ar mājkalpotāju, kas aprūpēja J. Roṇa vasarnīcu Jūrmalā un acīmredzot bija VDM aǵente, par to, ka viņš esot piesavinājies vasarnīcas teritorijā atrastās ieraktās vērtīgās lietas (traukus u.c.). ${ }^{67}$

Ne mazāk iespaidīga, lai gan beidzās nevis ar tiesas darbiem, bet ar atbrīvošanu no darba un aț̣auju izbraukt no Latvijas gimenes locekḷu slimības un paša lūguma dēḷ, bija CK sekretāra vietnieka (nodaļas vadītāja) celtniecības un būvmateriālu jautājumos Zota Čaščina darbība. Viṇu iecēla šajā amatā 1944. gada oktobrī. Jau drīz vien CK sāka saṇemt sūdzības par viņa pārliecīgo aizraušanos ar sadzīves apstākḷu uzlabošanu, turklāt ne tikai sev, bet arī kuplam radinieku pulkam. Kopā ar Z. Čaščinu no Čel̦abinskas Rīgā bija ieradies viṇa brālis un citi radinieki, un viṇiem 1945. gadā Rīgā izremontēti uz valsts rēķina pieci dzīvokḷi. Tas nebija vienīgais nodarījums. ${ }^{68}$

Latvijas kompartijas vadība bija diezgan uzmanīga un kūtra šādu darboṇu nosodīšanā. Iespējams, vismaz dal̦ēji tas izskaidrojams ar to, ka tie visi ietilpa Maskavas nomenklatūrā un bez saskaņošanas neko nevarēja uzsākt, tādēḷ to darīja tikai tad, kad sūdzību par viṇu izdarībām bija pietiekami daudz. Tādās vai citādās ḷaunprātībās, uzlabojot savu stāvokli, bija iejaukti ḷoti daudzi, lai gan ne vienmēr mēbel̦u un citu mantu piesavināšanās tika uzskatìta par nelikumīgu. Funkcionāriem bija iespējams iegūt "bezsaimnieka" vai "trofeju” mantas, par tām samaksājot cenu, kas visbiežāk bija zemāka par to patieso vērtību. Atškịiriba starp godīgu un blēdīgu 
nomenklatūras darbinieku bija tā, ka pirmais apmierinājās ar tādu dzīvokli (vai istabām komunālajā dzīvoklī), kādu viņam piešķīra, un pašapgādē ar mēbelēm ievēroja "normas", respektīvi, nesavāca vairāk, nekā gimenei bija nepieciešams pamatvajadzību nodrošināšanai, kā arī kārtīgi samaksāja nodevu valstij.

Ar laiku šādi brutāli dienesta stāvokḷa izmantošanas gadījumi augstākās nomenklatūras aprindās kḷuva daudz retāki. Vietējā partijas un padomju nomenklatūras aparāta augšslānis lielā mērā joprojām veidojās no cilvēkiem, kas bija atsūtīti no ārienes, tomēr viņi savu karjeru veidoja jau Latvijā, sākot ar zemākiem posteņiem un pamazām virzoties uz augšu, tādēl bija vieglāk savlaicīgi atsijāt cilvēkus, kuru uzvedība krasi atšḳ̂̄rās no vēlamās, un samazināt iespējamību viṇu nonākšanai augstākajos amatos. Partijas aparāta darbinieku rotācija republikas līmenī bija samērā augsta, it sevišķi apriņ̧̧̧u/rajonu/pilsētu partijas sekretāru līmenī. Tieši šajā līmenī arī notika kadru atlase augstākiem karjeras posmiem.

N̦. Hruščovs 50. gados mēgināja mazināt Staḷina laikā izveidojušās deformācijas, to skaitā arī nomenklatūras sistēmā, atskatoties uz pēcrevolūcijas laika komunistiskajiem ideāliem. Tika mēǵgināts modelēt zināmu uzvedības standartu, kā arī sakārtot nomenklatūras privilēǵiju sistēmu un apkarot dienesta stāvokḷa l̦aunprātīgu izmantošanu, kas gan nedeva būtiskus rezultātus ilgtermin̦ā. Taču N̦. Hruščovs gribēja iet vēl tālāk - viņš uzskatīja, ka jāapkaro jebkādas privātīpašnieciskas tieksmes, un trieciens tika vērsts pret namīpašumu (privātmājas un vasarnīcas), jo nomenklatūrai šie labumi it kā nemaz nebija nepieciešami, viņus ar dzīvokli nodrošināja valsts, tāpat viṇi vasaras sezonā varēja izmantot valsts vasarnīcas. 1960. gadā sākās Maskavas inspirēta kampaṇa visā Padomju Savienībā pret pārkāpumiem privātmāju būvniecībā. LKP CK ideologiskais sekretārs Augusts Voss CK plēnumā 1960. gada augustā norādīja, ka zemes gabali individuālo māju būvniecībā daudzos gadījumos pārsniedz normas un šādas mājas dažkārt ir iedzīvošanās avots (ar to bija domāta māju pārdošana par augstāku cenu nekā būvniecības vai iegādes izmaksas), turklāt šādus pārkāpumus ir izdarījuši ne tikai ministriju un resoru atbildīgi darbinieki, bet arī partijas darbinieki. ${ }^{69}$

Amata iespēju izmantošana savu dzīves apstākḷu uzlabošanai 70. gados pieṇēmās spēkā, un to veicināja gan ideologiskās motivā- 
cijas mazināšanās nomenklatūras uzvedībā un priekšstatos par ètiskajām normām, gan arī t.s. sabiedriskā patēriṇa fondu dotās iespējas. Iestāžu un uzņēmumu vadība, kam bija pietiekami lieli naudas līdzekḷi strādājošo sociālo vajadzību nodrošināšanai, varēja iegūt resursus personiskās labklājības uzlabošanai, piesedzoties ar rūpēm par kolektīva interesēm. Uzplauka vasarnīcu un dārzkopības kooperatīvi, kurus organizēja ministrijas, valsts komitejas un atsevišķas organizācijas, lai uzlabotu strādājošo atpūtas iespējas, bet kurās faktiski labākos zemes gabalus saṇēma dažāda ranga vadītāji. Organizācijas būvēja atpūtas bāzes ar saunām un vasaras mājiṇām, kuru izmantošanā priekšrocības bija priekšniecībai, turklāt nereti šādas bāzes faktiski pastāvēja nelegāli, kā tas bija ar Rīgas pilsētas Iekšlietu pārvaldes "telšu pilsētiṇu”, faktiski vasarnīcu kooperatīvu "Družba" 70 1977. gadā PSKP CK PKK un LKP CK pirmajam sekretāram A. Vosam bija nosūtītas anonīmas vēstules par LPSR MP Galvenās materiāli tehniskās apgādes pārvaldes priekšnieku V. Kronu. Galvenās apsūdzības bija saistītas ar to, ka par pārvaldes naudu 60.-70. gados uzbūvēti vairāki atpūtas objekti, kas tiek izmantoti paša V. Krona vajadzībām, - atpūtas bāze "Rēzna", somu pirts Jelgavas rajona sovhoza "Lielupe" teritorijā, sporta un veselības bāze "Boksti". ${ }^{11}$ V. Kronu atcēla no amata un uzlika partijas sodu, bet ne tik daudz par iestādes resursu izmantošanu, cik par nereageēšanu uz dažādiem pārvaldes vadošo darbinieku izdarītajiem pārkāpumiem, to skaitā par amorālu uzvedību un dzeršanu. Acīmredzot zināma ietekme bija tam, ka par viṇu jau bija žēlojušies un 1973. gadā viņš jau bija kḷuvis par kritikas objektu CK plēnumā. Ideologiskais sekretārs Aleksandrs Drīzulis viṇu minēja kā piemēru tam, ka vasarnīcas būvē arī priekšnieki, kam ir iespējas izmantot valsts vasarnīcas. ${ }^{72}$

70. gados vasarnīcu un dārzkopības kooperatīvu skaits strauji pieauga. Administratīvo resursu izmantošana bija skaidri saskatāma, jo labākos zemes gabalus saṇēma ietekmīgas un "vajadzīgas” iestādes. Nevar teikt, ka kontrolējošās iestādes šim jautājumam nepievērstu uzmanību, piemēram, 1973. gadā jau pieminētajai "Družbai" un Zinātṇu akadēmijas vasarnīcu kooperatīvam "Mežciems". Izrādījās, ka ZA vasarnīcu kooperatīvā lielākā daḷa dalībnieku nebija saistīti ar zinātni ${ }^{73}$ bet bija uzṇēmumu un pārvalžu priekšnieki un priekšnieku vietnieki, kas varēja būt noderīgi kooperatīvam dažādu 
praktisku jautājumu risināšanā. Tā kā sankcijas pret atsevišķiem vadītājiem nedeva rezultātus, 1982. gada 11. maijā LKP CK birojs uzdeva rajonu izpildkomitejām trīs mēnešu laikā veikt visu vasarnīcu un dārza mājiṇu inventarizāciju. ${ }^{74}$ Jautājuma izskatī̌̌ana birojā balstijjās uz LKP CK Partijas orgānu nodaḷas, Partijas komisijas un Vispārējās nodaḷas sagatavoto kopīgo informāciju, kurā bija plaši aprakstītas dažādas nelikumības, dienesta stāvokḷa izmantošana, nosauktas iesaistītās amatpersonas. ${ }^{75}$ Apsekojuma mērḳis bija atklāt dažādas blēdības, to skaitā apdzīvojamās platības paplašināšanu uz verandu, pagrabu, bēniņu un saimniecības telpu rēḳina, vasaras mājiņu pārbūvēšanu par apkurināmām kapitālām èkām, kā arī gadījumus, kad vienas ğimenes locekḷiem piederēja vairākas vasarnīcas.

Atsevišķu gadijumu izgaismošana un amatpersonu sodī̌̌ana lika pārējiem uzmanīties un apdomīgāk izmantot administratīvos resursus savas labklājības uzlabošanai, taču nomenklatūra visumā arvien vairāk "apauga ar mantu”. Piesardzīgākie noformēja automašīnas, dārza mājiṇas, lauku mājas uz bērniem, vecākiem utt. Sodāma bija spekulācija ar automašīnām, jo nereti dažāda ranga vadītāji izmantoja savu dienesta stāvokli, lai par valsts noteikto cenu pirkto automašīnu pārdotu krietni dārgāk un drīz pēc tam nopirktu jaunu automašīnu.

Vēl viena problēma, kas 70. gados bija kḷuvusi par vispārēju parādību, bija dažādu banketu un vienkārši iedzeršanu rīkošana darbavietās, nereti par iestāžu līdzekḷiem. 1980. gada augustā LKP CK birojs pien̦ēma lēmumu par iedzeršanu nepiel̦aušanu uzṇēmumos, iestādēs un sabiedriskās organizācijās. ${ }^{76}$ Tā nebija vietējā iniciatīva, bet gan atbilde uz attiecīgu PSKP CK lēmumu. Turklāt kā Maskavas, tā arī vietējais lēmums bija vispārējs, runa bija par "atsevišķām” parādībām. Kārtības ieviešanas kampaṇa nesekoja. Tomēr lēmumi signalizēja, ka problēma pastāv.

Jubileju svinēšana un banketi par valsts līdzekḷiem izteikti parādīja, ka viens no komunista ētikas deklarētajiem principiem - personīgā pieticība - tiek atklāti un pat uzsvērti ignorēts. Laiku pa laikam šādi pasākumi kḷuva par iemeslu sūdzībām, kas tika sūtītas Maskavai. Tā 1975. gadā no amata atcēla bagātā zvejnieku kolhoza “9. maijs” priekšsēdētāju Konstantīnu Vìtolu, sodīja arī partijas komitejas sekretāru un viņa vietnieku, kā arī izteica aizrādījumu Zvejnieku kolhozu savienības valdes vadībai. ${ }^{77}$ Šajā gadījumā tika inkri- 
minēta ne tikai priekšsēdētāja jubilejas svinēšana, bet arī banketi sakarā ar citiem notikumiem, piemēram, kugiu atgriešanos no tāljūras zvejas, ārzemju delegāciju uzņemšanu. Tāpat priekšsēdētājs tika vainots dažādos citos pārkāpumos.

Bagātie kolhozi bija sava veida Padomju Latvijas labklājības vizìtkarte, jo to biedriem bija laba izpel̦ṇa un dzīves apstākḷi. Kolhozi arī brīvāk nekā valsts saimniecības varēja rīkoties ar saviem līdzekḷiem, tādēḷ tie uzturēja mūzikas grupas un solistus, visāda veida pašdarbības kolektīvus u.tml. Protams, ka tas, ko varēja atḷauties bagāto kolhozu priekšsēdētāji, daudziem skauda. Neapmierināto un aizvainoto pietika arī pašos kolhozos, jo šādu kolhozu priekšsēdētāji pārsvarā bija autoritāra tipa vadītāji. Lai veicinātu sava kolhoza labklājību, priekšsēdētājs bieži balansēja uz likuma robežas vai to arī pārkāpa. Kā raksta žurnālists Aivars Berķis: "Kolhozu laikā iedibinātās tradīcijas tagad sauktu par korupciju, par kukul̦došanu, par dienesta stāvokḷa l̦aunprātīgu izmantošanu... [..] Padomju likumsargiem šajā ziṇā bija citāda pieeja: par kukuḷdošanu sodīja, ja kāds to darīja, lai vairotu savu personīgo labklājību. Valsts un kooperatīvo struktūru darījumi bija savstarpēja izpalīdzēšana, iniciatīvas stimulēšana - viss kas, tikai ne noziegums." 78 Sūdzības par bagāto kolhozu vadìtājiem, to skaitā arī Maskavai adresētās, bija parasta parādība, taču tās tikai retumis noveda pie tik smagām sankcijām, kā tas bija K. Vìtola gadījumā, vēl jo vairāk tādēl, ka viņš bija bijušais frontinieks. Iespējams, viṇš bija izvēlēts par biedinājumu citiem kolhozu priekšsēdētājiem, turklāt viṇa stāvokli pasliktināja tas, ka viņš jau iepriekš bija sodīts par dienesta stāvokḷa ḷaunprātīgu izmantošanu.

1979. gadā PSKP CK PKK izskatīja anonīmu vēstuli, kas bija saṇemta par jubileju svinēšanām Valkas rajonā. Rajona izpildkomitejas priekšsēdētāja L. Leimaṇa 50 gadu jubilejā bija rīkots bankets 80 personām, kuras izklaidēja estrādes orḳestris un sieviešu vokālais ansamblis. Jubilārs bija saṇēmis dārgas dāvanas. Ar līdzīgu vērienu bija svinētas arī partijas komitejas sekretāra A. Inkina 50 gadu un citu vadošo darbinieku jubilejas. Vainīgie tika sodīti, bet sodi bija samērā mēreni - abiem pieminētajiem jubilāriem rājiens, bet rajona pirmajam sekretāram V. Avotam tika izteikts aizrādījums. ${ }^{79}$ Tomēr, kā jau teikts, šāda mēroga jubileju svinēšana nekādā ziṇā nebija izṇēmums, tā bija tipiska parādība. 
Daudzi padomju sistēmas pētnieki uzskata, ka valsts centās dažādos veidos regulēt gimenes dzīvi. ${ }^{80}$ Tomēr amerikāṇu vēsturnieks Jurijs Sḷozkins raksta, ka gimene vispār bija boḷševiku politikas vājais punkts. Partijas organizācijas darbojās pēc teritoriālā un ražošanas principa, pēc šā principa notika arī ideologiskais darbs, bet ǵimene no šīs sistēmas izkrita. "Teorijā gimenes dzìve bija sociālistiskās celtniecības neatņemama daļa; praksē gimene bija autonoma un slēpta no svešām acīm." ${ }^{81}$ Lai gan komunistiskās ètikas principi prasīja pieticību materiālā ziṇā, noteikto ienākumu un materiālā nodrošinājuma normu nepārkāpšanu un mērenību personīgajā/ gimenes dzīvē (neaizraušanos ar alkoholu, kārtīgu gimenes dzīvi, piedalīšanos bērnu audzināšanā), partijas organizāciju redzeslokā gimenes dzives problēmas parasti nonāca tikai pēc gimenes locekḷu vai kaimiņu sūdzībām vai arī gadījumos, kad dzeršana un citi sadzīves normu pārkāpumi kḷuva publiski un nopietni apdraudēja ne tikai paša vainīgā funkcionāra, bet arī viṇa pārstāvētās iestādes reputāciju.

Kara laikā un uzreiz pēc kara partijas-valsts politikā Padomju Savienībā gimenes nostiprināšanai bija daudz lielāka nozīme nekā pirms kara. Notika pilnīga atteikšanās no 20. gados piekoptās nihilistiskās attieksmes pret gimeni kā pret "buržuāziskā dzivesveida" izpausmi. Pieauga sieviešu sūdzību skaits par vīru neuzticību, alimentu nemaksāšanu utt. To izsauca vairāki apstākḷi: 1944. gadā pieņemtās izmaiņas likumdošanā, kas padarīja daudz sarežg̀ītāku un dārgāku šḳiršanos, vīriešu trūkums pēc kara un tā izraisītā konkurence, ǵimenes saišu pavājināšanās kara laikā, kad vīriešiem bieži vien bija radušās jaunas gimenes utt. ${ }^{82}$ Jāpiebilst, ka nomenklatūras augstākajos slāņos laulības šḳiršana sievai bieži vien nozīmēja ārkārtīgi krasu statusa un labklājības līmeṇa pazemināšanos, un, lai to saglabātu vai arī atriebtos, ja laulību neizdevās saglabāt, daudzas bija gatavas uz visu, tajā skaitā politiskām denunciācijām, kas gan biežāk vērsās nevis pret dzīvesbiedru, bet pret viņa jauno simpātiju. To ilustrē Inetas Lipšas aprakstītais gadījums, kad dažādām instancēm sūtītās anonīmās denunciācijas 1949.-1950. gadā par iekšlietu ministra Augusta Eglīša sakaru ar kādu jaunāku sievieti galu galā noveda pie viņa atcelšanas no amata. ${ }^{83}$ Tomēr šķiet, ka tik smagas sekas bija drīzāk izṇēmums, kuras izraisīja kādi blakus apstākḷi, lai gan visumā šajā laikā nomenklatūras, bet it sevišḳi partijas aparāta 
darbiniekam šķiršanās bija nevēlams traips biogrāfijā, un tika veicināta vismaz formāla gimenes saglabāšana, ja tas bija iespējams. Šḳiršanās gadījumā obligāta prasība bija materiāli palīdzēt bērniem. Tas attiecās arì uz bērniem no ārlaulības sakariem.

Pēckara gados laiku pa laikam partijas institūcijas pievērsa pastiprinātu uzmanību tam, kā komunisti audzina savus bērnus. Tas bija saistīts nevis ar politisku indoktrināciju, bet gan ar periodiskām pusaudžu un jauniešu noziedzības un huligānisma pieauguma izpausmēm 40.-50. gados. Nereti arī funkcionāru bērni skolā slikti mācījās, klaiṇoja, bija iesaistīti noziedzīgos grupējumos utt., un cēlonis ne vienmēr bija nesodāmības apziṇa, ko izraisīja vecāku stāvoklis, bet arī vecāku noslogotība darbā, politiskās un saimnieciskās kampaṇās.

Partijas - valsts centieni ietekmēt gimeni pastiprinājās 50. gadu beigās un 60. gadu sākumā. Darba kolektīviem, arodbiedrībām, partijas organizācijām faktiski tika uzlikts par pienākumu piedalīties konfliktu risināšanā, tostarp gadījumos, kad runa bija par vardarbību gimenē un asociālu uzvedību, arī ar biedru tiesu starpniecību. Tomēr publiska gimenes konfliktu risināšana radīja zināmu neērtības sajūtu, un partijas pirmorganizācijas no tās centās izvairīties. Likumdošanas izmaiņas, kas padarīja šķiršanos vieglāku, un sabiedrības attieksmes pārmaiṇas noteica to, ka arī nomenklatūras aprindās laulības šķiršana un jaunas gimenes nodibināšana vairs netika vērtēta tik negatīvi kā iepriekš, lai gan visumā attieksme pret to nebija pozitīva. Galvenais bija rīkoties atbilstoši vispārpieņemtajām normām un iztikt bez skandāliem. Tā Rīgas pilsētas Kirova rajona partijas komiteja 1972. gada martā sodỉja ar stingro rājienu ar ierakstu kādas pārvaldes priekšnieka vietnieku par "amorālu uzvedību sadzīvē, bezatbildīgu attieksmi pret laulības šķiršanu un noslēgšanu", bet gadu vēlāk sods bija anulēts, jo "pēdējo laulību ir noformējis, aktīvi piedalās partijas organizācijas sabiedriskajā dzīvē". 84

Laulības pārkāpšana nereti kombinējās ar citiem nodarījumiem - dzeršanu, vardarbību ğimenē, nolaidību darbā. Dzeršana nenoliedzami bija viens no visizplatītākajiem netikumiem visus padomju varas gadus. Uzreiz pēc kara tā bija ārkārtīgi bieži sastopama, it sevišķi čekistu, miliču un arī partijas darbinieku vidū. Tā bija pieejamākā relaksācijas forma, īpaši cilvēkiem, kam nebija nekādu hobiju. Augstākā nomenklatūra par dzeršanu, it sevišḳi, ja tā 
bija saistīta ar citiem nodarījumiem, varēja tikt sodìta pietiekami bargi. Tā 1948. gadā CK birojs mežrūpniecības ministru Jāni Gustsonu sodīja ar stingro rājienu ar ierakstu uzskaites kartītē par dzeršanu un nepartijisku uzvedību, un viņš arī zaudēja ministra amatu. ${ }^{85}$ No Augstākās padomes priekšsēdētāja amata atcēla Aleksandru Mazjēci un 1948. gada 28. septembrī viņam uzlika stingro rājienu ar ierakstu par dzeršanu un politiskās modrības zaudēšanu. ${ }^{86}$

Dzeršana 40. un pat 50. gados l̦oti bieži bija saistīta ar šaujamieroču lietošanu un dažādiem vardarbīgiem ekscesiem, jo ne tikai čekistiem un miličiem, bet arī partijas darbiniekiem bija personīgie ieroči. Tā 1947. gadā prokuratūra izmeklēja Viḷakas apriņķa komitejas kadru sekretāra Arnolda Lerha vairākkārtēju šaudīšanos ar ieročiem dzērumā. Vienā epizodē viņš bija iešāvis kājā savam šoferim. Tomēr Viļakas apriņķa komitejas birojs izlēma, ka "apsūdzība sistemātiskā dzeršanā nav apstiprinājusies, lai gan iedzeršanas laiku pa laikam ir bijušas", un par neuzmanīgu apiešanos ar ieročiem sodīja ar rājienu ar ierakstu personas lietā. ${ }^{87}$ Viens no gadījumiem, kuru piẹ̦āva augsta ranga funkcionārs, bija skandāls ar ieroču pielietošanu, ko Centrāltirgus gal̦as paviljona noliktavās dzērumā sarīkoja valsts drošības ministra vietnieks Viktors Kozins. Tas beidzās ar LK(b)P CK biroja 1951. gada 26. oktobra lēmumu atcelt vinu no darba par pl̦ēgurošanu ar padotajiem un sakariem ar apšaubāmas uzvedības sievietēm. ${ }^{88}$ Iespējams, šajā gadijumā soda lielumu noteica ne tikai skandāla publiskais raksturs, bet arī tas, ka tas notika laikā, kad bija sākusies J. Staḷina inspirētā kampaṇa par kārtības ieviešanu Valsts drošỉbas ministrijā. Ministra Alfona Novika mēginājums noklusēt skandālu veicināja ministra atcelšanu no amata.

Arī pēc Staḷina nāves atbildīgiem ierēdņiem stresa pietika, iedzeršanas turpinājās, bet tās tika institucionalizētas dažādu banketu un citu pasākumu formā. Lai gan LKP CK pirmie sekretāri J. Kalnbērziņš un A. Pelše neaizrāvās ar alkoholisko dzērienu lietošanu, ${ }^{89}$ politika šajā jautājumā viṇu laikā maz atšḳīās no attieksmē pret alkoholu daudz pielaidīgākā un askētisku dzīvesveidu nepiekopjošā A. Vosa laikā.

LKP CK Partijas komisijas izzin̦ā par nomenklatūras darbinieku sodīšanas politiku 1972.-1973. gadā ir dots šāds novērtējums: "vairākas partijas komitejas, neskatoties uz nopietniem trū- 
kumiem atsevišḳu uzṇēmumu un iestāžu vadītāju darbā, morāli ètisko normu pārkāpumiem, kurus piel̦auj daži vadoši darbinieki, nepietiekami principiāli novērtē šādas parādības, reizēm izrāda samierniecisku attieksmi pret darbiniekiem, kas uzvedas nepareizi, kompromitē vadītāja nosaukumu [izcēlumi mani. - D. B.]." ${ }^{90} \mathrm{Bu}-$ tībā tas visai kodolīgi raksturo attieksmi pret partijas ètikas pārkāpumiem 70. gados - tie nekādi netika uzskatīti par sistēmisku parādību.

\section{SECINĀJUMI}

Partijas sodiem bija svarīga loma, lai nodrošinātu noteiktu morālo standartu ievērošanu vienīgajā un valdošajā partijā Padomju Savienībā. Galvenā dilemma, ar kuru saskārās kompartija, bija tā, ka, nepastāvot partiju konkurencei un pilsoniskai sabiedrībai, kas varētu kritizēt komunistus par ètisko normu neievērošanu, pastāvīga problēma bija tendence pazemināt standartus. Partijas sodu sistēma bija ierobežojošs faktors totālai morālai degradācijai un neierobežotai varas izmantošanai personīgās interesēs. Cìṇai pret ètisko standartu pazemināšanos partijā visumā bija raksturīga kampaṇveidība. Kampaṇu mērḳis bija ne tik daudz izskaust negatīvās parādības vispār, cik tās ierobežot. Kad kāds ètikas normu pārkāpums bija ieguvis tādu izplatību, ka sāka būtiski traucēt partijas prestižam, tika sodīts zināms skaits vainīgo, lai pārējiem atgādinātu, kāda rīcība nav vēlama.

Izņemot ārkārtīgi retus gadījumus, pats sodīšanas fakts un iemesli netika atklāti ne tikai plašākai sabiedrībai, bet bieži vien palika apslēpti arī partijas biedriem, kas nebija tieši iesaistīti jautājumu risināšanā. Slepenībai šajā ziṇā laika gaitā bija tendence pieaugt, un nereti Latvijas Komunistiskās partijas CK biroja lēmumos par sodīšanu, kā arī PSKP CK Partijas kontroles komitejas lēmumos par apelāciju izskatīšanas rezultātiem nodarījuma raksturs ir formulēts aptuveni. Plašāka sabiedrība par nomenklatūras pārkāpumiem tika informēta tikai atsevišķos gadijumos un nereti tendenciozi.

Signālus par nomenklatūras veiktajiem partijas ètikas pārkāpumiem kontroles institūcijas l̦oti bieži san̦ēma anonīmu vēstuḷu formā, turklāt, neuzticoties vietējām varas iestādēm, sūdzētāji ḷoti 
bieži vērsās tieši Maskavā. Staļina laikā anonīmo vēstul̦u autori, lai panāktu sodīšanu, apsūdzības l̦oti bieži pastiprināja ar politiska rakstura pārkāpumiem. Sākot ar 50. gadu vidu, šāda prakse samazinājās, lai gan joprojām signāli par biogrāfijas datu slēpšanu, sakariem ar politiski nevēlamām personām vai cita veida tīri politiskiem pārkāpumiem varēja tikt izmantoti, lai palielinātu apsūdzību svaru. Tomēr 70. gados sūdzības kḷuva mazāk politizētas. Priekšniecības veiktos pārkāpumus sūdzētāji, tajā skaitā arī anonīmās vēstulēs, vairs necentās pastiprināt ar faktiem par biogrāfijas faktu slēpšanu, draudzību ar politiski šaubīgām personām u.tml. Jāpiebilst, ka partijas institūcijas, kas šìs sūdzības izskatīja, arī necentās atrast šķiriskus motīvus pārkāpumos.

Partijas institūcijas Staḷina laikā labprāt sasaistīja saimnieciskus vai sadzīves morāles pārkāpumus ar politiskām apsūdzībām, cenšoties parādīt, ka saimnieciski vai politiski pārkāpumi ir sodāmās personas nepareizas šķiriskās izcelsmes, privātu sakaru vai arī morāla pagrimuma rezultāts. Šāda prakse vēlāk jūtami mazinājās, taču tika lietota 60. gadu sākumā pret cilvēkiem, kurus apsūdzēja "buržuāziski nacionālistiskās" novirzēs.

Kompartija nelabprāt iejaucās nomenklatūras privātajā dzīvē, un gadījumos, kad nācās sodīt cilvēkus, kas tika apsūdzēti par ǵimenes un sadzīves morāles pārkāpumiem, dzeršanu un citiem tamlīdzīgiem nodarījumiem, tas nereti notika ar vilcināšanos un izvairīgi, it sevišķi, ja runa bija par cilvēkiem, kas sekmīgi pildīja amata pienākumus.

Visizplatītākais partijas ētikas pārkāpums nomenklatūrā bija dienesta stāvokḷa izmantošana, kas varēja izpausties visdažādākajās formās: pirmajos pēckara gados nereti kā atklāta laupišana, vēlākajos gados tā visbiežāk izpaudās kā amata dẹl pieejamo valsts resursu izmantošana personīgās labklājības vairošanā. Tieši šajā jomā visskaidrāk redzamas nomenklatūras korporatīvās morāles izmaiņas. 60.-70. gados komunista-askēta ideāltips jau vairs bija tikai ideologiska čaula, un N̦. Hruščova laikā notikušie mēginājumi to atdzivināt izrādījās nesekmīgi. Nomenklatūra vēlējās baudīt savas varas aug̣̦us, bet partijas oficiālā morāle, kas nosodīja "apaugšanu ar mantu” un dažādu privilēgiju izmantošanu, arvien vairāk nonāca pretrunā ar nomenklatūras uzskatiem. 


\section{ATSAUCES UN PIEZİMES}

1 Mikhail Voslensky (1984). Nomenklatura: Anatomy of the Soviet ruling class. London: Bodley Head.

2 Mike Bowker (1 April 1985). Nomenklatura: anatomy of the Soviet ruling class. International Affairs, 61 (2), p. 320 . https://doi.org/10.2307/2617527

3 Sheila Fitzpatrick (2005). Tear Off the Masks! Identity and Imposture in Twentieth-Century Russia. Princeton, N. J.: Princeton University Press; Edward D. Cohn (2009). Sex and the Married Communist: Family Troubles, Marital Infidelity, and Party Discipline in the Postwar USSR, 1945-64. The Russian Review, 68 (3), pp. 429-450.

4 Izziņa par 1971.-1973. gadā sodītajiem nomenklatūras darbiniekiem. Latvijas Nacionālā arhīva Latvijas Valsts arhìvs (turpmāk: LVA), PA-2160-35105, 1.-3. lp.

5 Turpat.

6 Kiril A. Iudin (2015). Vnutripartiinyi kontrol'v SSSR 1930 - nachala 1940-kh gg.: ideino-institutsional'nyi oblik. Ivanovo; Viktor V. Nikulin (2014). Bol'sheviki i partiinaia etika: povedencheskie normy, sotsial'nyi kontrol' i vnutripatiinaia povsednevnost' (1920-e gody). Sotsiodinamika, 8, s. 26-82. DOI: 10.7256/2306-0158.2014.8.13062. URL: http://e-notabene.ru/pr/article_13062.html

7 V. V. Kondrashin (2015). "Nomenklaturnaia revoliutsiia" v Penzenskom obkome VKP(b) v poslevoennyi period. V kn.: Sovetskoe gosudarstvo i obshchestvo $v$ period pozdnego stalinizma. 1945-1953 gg. Moskva: ROSSPEN; prezidentskii tsentr B. N. Eltsina, s. 261-269; A. B. Konovalov (2015). Sistema vzaimootnoshenii partiinoi nomenklatury tsentra i regionov v period pozdnego stalinizma: instituty, traditsii, praktiki, 19451953 gg. Turpat, 270.-279. lpp.; O. N. Kalinina (2015). Sovetskaia nomenklatura i sistema vnutrikorporativnoi okhranit'elnosti v pozdnestalinskii period (1946-1953 gg.). Turpat, 304.-312. lpp.

8 Sk., piem.: Represijas Latvijas laukos 1944-1949: Dokumenti un materiāli (2000). Rīga: Latvijas Valsts arhīvs.

9 Ineta Lipša (2016). Privātās dzīves uzraudzīšana un kontrole LPSR (19441953), izmantojot valsts represīvos mehānismus. Pieejams: https://www. lu.lv/fileadmin/user_upload/lu_portal/projekti/vdkkomisija/120_Lipsa_ RED_2016-03-03marts_23-30_Privatas_dzives_uzraudzisana_LPSR.pdf

10 Lìdz 1952. gada oktobrim - Latvijas Komunistiskā (boḷševiku) partija (LK(b)P).

11 Līdz 1952. gada oktobrim - Vissavienības Komunistiskā (boḷ̌šviku) partija (VK(b)P).

12 Nikulin. Bol'sheviki i partiinaia etika.

13 A. A. Sol'tz (1924). O partiinoi etike. V kn.: Partiinaia etika: Dokumenty $i$ materialy diskussii 20-kh godov. (Moskva: Izdatel'stvo politicheskoi literatury, 1989), s. 260-261. Tulkojums no krievu val. 
$$
\text { 46. lpp. }
$$

(Dienibas Komunistiskās partijas statüti. Pieneêmis partijas XIX kongress. (Daḷejus labojumus izdarīis PSKP XX kongress). Rīga: Latvijas Valsts izdevniecība, 1958, 10. lpp.

17 Ustav Kommunisticheskoi Partii Sovetskogo Soiuza. Moskva: Izdatel'stvo politicheskoi literatury, 1984, s. 28.

Sk., piem., LKP CK biroja lēmumu 21.07.1975. LVA, PA-101-39-13, 163. lp.

LK(b)P CK biroja lēmums 19.08.1952. LVA, PA-101-15-63, 218. lp.

E. Beišāna personas lieta. LVA, PA-15500-1-580, 18. lp.

LK(b)P CK biroja sēdes stenogramma 19.08.1952. LVA, PA-101-15-63, 223.-224. lp. Tulkojums no krievu val.

E. Beišāna personas lieta. LVA, PA-15500-1-580, 28. lp.

Turpat, 34. lp. Tulkojums no krievu val.

E. Beišāna lieta. LVA, PA-2160-20-32, 5. lp.

Turpat, 12. lp.

Izziṇa par Rīgas pilsētas Kirova rajona partijas organizācijas sastāvu 1979. gadā. $L V A$, PA-106-51-13, 9. lp.

LK(b)P CK biroja sēdes protokols 29.12.1940. LVA, PA-101-1-12, 14. lp. Kārlis Gailis (1903-1973), no 1944. gada marta līdz 1947. gada aprīlim CK Partijas kolēgijas sekretārs, pēc tam Augstākās padomes Prezidija (APP) priekšsēdētāja vietnieks, bet no 1948. gada jūlija - APP sekretārs.

Moisejs Aršs (1911-1984), no 1944. gada aprịḷa līdz 1947. gada oktobrim Partijas kolēgijas loceklis.

Alīda Sīkstule (arī Sīkstulis, 1900-1952), 1945.-1952. gadā Partijas kolēgèijas locekle.

Pēteris Plēsums (1895-1968), 1947.-1953. gadā LKP CK Partijas kolēgijas sekretārs, līdz 1960. gada maijam - LKP CK Partijas komisijas priekšsēdētājs.

P. Plēsuma personas lieta. LVA, PA-15500-2-3808.

Roberts Ķīsis (1896-1981), 1960.-1973. gadā LKP CK Partijas komisijas priekšsēdētājs.

Pjotrs (arī Pēteris) Ribalččnko (1917-2007), 1973.-1985. gadā CK Partijas komisijas priekšsēdētājs.

5 Stepans Paljora (1934-1992?), 1985.-1990. gadā LKP CK Partijas komisijas, pēc reorganizācijas Partijas kontroles komisijas, Centrālās kontroles un revīzijas komisijas priekšsēdētājs.

P. Ribalıčenko parakstìta pavadvēstule 1980. g. aprīili. LVA, PA-2160-42-38, 18. lp.

LKP CK Partijas komisijas 1973.-1976. gadā sagatavoto jautājumu saraksts. LVA, PA-2160-38-59, 1.-3. lp. 
38 Marta Krustiņsone (1895-1996), PSKP biedre kopš 1912. gada.

39 LKP CK Prezidija lēmums 22.01.1963. LVA, PA-101-26-27, 273.-274. lp.

40 Izziņa par PK, RK partijas komisiju sastāvu un LKP CK Partijas komisijas darbu 1973.-1974. gadā. LVA, PA-2160-36-72, 4. lp.

41 Izziņa par LKP CK Partijas komisijas izskatītajām lietām. LVA, PA-216038-59, 7. lp.

42 Saraksts ar 1948. gadā LK(b)P CK biroja sēdēs sodìtajiem komunistiem. LVA, PA-101-11-128, 165.-169. lp.

43 LKP CK biroja lēmums 03.08.1979. LVA, PA-101-44-11, 15. lp.

44 P. Pizāna personas lieta. LVA, PA-15500-2-3753.

45 V. Ruskuḷa personas lieta. LVA, PA-15500-2-7890.

46 A. Lūriṇa personas lieta. LVA, PA-15500-2-2409, 49.-64. lp.

47 E. Mūkina personas lieta. LVA, PA-15500-2-3008, 33. lp.

48 LKP CK birojam iesniegts Partijas komisijas slēdziens. LVA, PA-101-3743, 191.-192. lp.

49 Jūlijs Beḷavnieks (2011). ... bet tā bija! Rīga: Trīsdesmit seši, 46., 64., 80., 268. lpp.

50 Turpat, 274. lpp.

51 LKP Ogres rajona komitejas biroja lēmums 25.11.1970. LVA, PA-4140-318, 170. lp.

52 L,enina rajona sodīto nomenklatūras darbinieku saraksts. LVA, PA-216035-105, 13. lp. Tulkojums no krievu val.

53 J. Lūša (Lūsa) personas lieta. LVA, PA-15500-2-2418, 11.-12. lp.

54 Turpat, 17. lp.

55 Partijas kolēgijas slēdziens par Alūksnes apriṇķa partijas komitejas lēmumu A. Sluča lietā. $L V A, P A-101-12-59,257$. lp.

56 A. Zandmaña personas lieta. LVA, PA-15500-2-337, 8., 20. lp.

57 LK(b)P CK Kadru daļas vadītāja vietnieka Vasiḷjeva vēstule L,enina rajona partijas komitejas pirmajam sekretāram J. Kacenam 10.12.1947. LVA, PA101-10-56, 211. lp.

58 Sỉkāk par šiem gadījumiem sk.: Daina Bleiere (1993). Kartīšu sistēma Latvijā 1944.-1947. gadā. Latvijas Vēstures Institūta Žurnāls, 1, 104. lpp.

59 LK(b)P CK sēdes stenogramma 05.08.1952. LVA, PA-101-15-63, 59. lp. Tulkojums no krievu val.

60 LK(b)P Daugavpils apgabala komitejas biroja lēmums 10.07.1952. LVA, PA101-15-63, 21.-22. lp.

${ }^{61}$ LK(b)P CK sēdes stenogramma 05.08.1952. LVA, PA-101-15-63, 59. lp.

62 LK(b)P CK atbildīgā organizatora Guseva ziņojums CK sekretāriem J. Kalnbērziņam, I. L,ebedevam, F. Titovam un A. Pelšem 16.12.1948. LVA, PA-101-11-128, 144.-147. lp.

63 LVA, PA-101-9-36, 252.-253. lp.

64 VK(b)P CK Partijas kontroles komisijas lēmums 13.05.1948. LVA, PA2160-32-2, 16. lp. 
Lēmums A. Puhovicka apelācijas lietā. LVA, PA-2160-32-2, 20. lp.

LVA, PA-101-11-18, 63.-64. lp.

LK(b)P CK kadru sekretāra F. Titova vēstule VK(b)P CK Kadru pārvaldes nodaļas vadītāja vietniekam M. Turkinam. $L V A$, PA-101-10-55, 67.-68. lp. Z. Čaščina personas lieta. LVA, PA-15500-2-6359.

Latvijas KP Centrālajā Komitejā. Cīna, 17.09.1960.

LKP CK biroja lēmums 12.07.1974. LVA, PA-101-38-19, 138.-139. lp.

LVA, PA-2160-39-54, 1.-4. lp.

LVA, PA-101-37-5, 19. lp.

Turpat.

LKP CK biroja lēmums 11.05.1982. LVA, PA-101-49-14, 9. lp.

Turpat, 57.-60. lp.

LVA, PA-101-45-16, 64.-65. lp.

LKP CK biroja lēmums 21.01.1975. LVA, PA-101-39-13, 162.-164. lp.

Alberts Kauls triumfā un trağismā (2010). Rīga: Jumava, 75. lpp.

LKP CK biroja lēmums 21.11.1979. LVA, PA-101-44-14.

Šādu viedokḷu izklāstu sk.: Lipša. Privātās dzīves uzraudzīšana un kontrole LPSR (1944-1953), izmantojot valsts represīvos mehānismus.

Iurii Slezkin (2019). Dom pravitel'stva: saga o russkoi revoliutsii. Moskva: AST, s. 563.

Fitzpatrick. Tear Off the Masks!, pp. 240-243, 249-261.

Lipša. Privātās dzīves uzraudzīšana un kontrole LPSR (1944-1953), izmantojot valsts represīvos mehānismus, 7.-10. lpp.

LVA, PA-2160-35-105, 11. lp. Tulkojums no krievu val.

LK(b)P CK biroja 1948. gadā sodīto komunistu saraksts. LVA, PA-101-11128, 165. lpp.

LK(b)P CK biroja protokols 28.09.1948. LVA, PA-101-11-16.

LK(b)P Viḷakas apriṇķa partijas komitejas biroja slēgtās sapulces protokola izraksts. LVA, PA-101-10-56, 29. lp. Tulkojums no krievu val.

Izraksts no LK(b)P CK biroja lēmuma V. Kozina personas lietā. LVA, PA15500-2-1290, 6. lp.

Aculiecinieka ieskatu J. Kalnbērziña un A. Pelšes attieksmē pret dzeršanu un banketiem sk.: Jānis Liepiņš (2008). Sarkano okupantu orgíijas Latvijā. Rīga: Domas spēks, 223.-228. lpp.

LVA, PA-2160-35-105, 5. lp. Tulkojums no krievu val. 


\section{COMMUNIST ETHICS AS AN INSTRUMENT \\ OF CONTROL OF NOMENKLATURA CONDUCT IN THE POLICY OF THE LATVIAN COMMUNIST PARTY} $(1944-1982)^{*}$

\section{Daina Bleiere}

Dr. hist., senior researcher of the Institute of History of Latvia, Latvian University.

Research interests: the Latvian history of the 20th century, impact of the Soviet regime on the society of Latvia

The paper deals with a problem that so far has not come under scrutiny in historiography of Latvia - a system of control and punishments established by the Communist Party in order to regulate the conduct of nomenklatura. The paper is based on archives of institutions of the Latvian Communist Party, and it analyses the fundamental principles of the Party ethics, punishments and controlling institutions, as well as developments of the policy of penalties for such violations of the Party ethics as loss of class vigilance, abuse of power for personal benefit and breaches of social life morality.

Key words: Party ethics, nomenklatura, Party control, principle of class awareness, abuse of power for personal benefit, social life morality.

\section{Summary}

The basic ethic principles of conduct of the Communist Party member, which were obligatory for the Latvian Communist Party member in 1944-1982, were formulated in the Soviet Union in the 1920s, they were based on the class principle, and this meant that ethical was everything that helped the Party to reach its goals. Drinking, adultery, using one's official position for personal benefit etc. were unethical not because such behaviour was immoral from the universal ethical point of view, but because it could be an obstacle for the effectiveness of a person in building of communism. Already in the 1920s, a system of the Party punishments and control institutions started to develop.

The aim of the paper is to show how the system of punishments and control was run by the Latvian Communist Party in combatting violations

* The article has been worked out within the framework of the Research Programme "Territory of Latvia as an Area of Interaction of Various Cultural Spaces, Religious, Political, Social and Economic Interests for Prehistory to Present-Day". 
of norms of the Party ethics in 1944-1982. This problem so far has not been researched enough in the Latvian historiography. The article is based mainly on three main collections of the Latvian State Archives: collection of the Latvian Communist Party (LCP) Central Committee (CC) (PA-101), collection of the nomenklatura personal files (PA-15500) and collection of the LCP CC Party Commission (PC).

Although the Party statistics is incomplete and contradictory as regards penalties of nomenklatura, available materials show that for the LCP members and candidates in general the most frequent reason for punishment were breaches of everyday behaviour: drinking, adultery, family violence, etc. For nomenklatura the most part of punishments was for dereliction of official duties. A comparatively small number of functionaries were punished for breeches of the Party ethics such as lack of class awareness, use of official position for personal benefit, drinking, immoral behaviour in personal life.

In the first post-war years hiding of biographical data and connections with "class enemies" were very widely interpreted and often used as an excuse for Party punishments and exclusion from the Party. It was widely used by authors of anonymous complaints in order to increase the weight of accusations induced by neglecting job duties or family conflicts. After Stalin's death, the number of such cases decreased. It should be mentioned that the attitude of Party institutions in cases when hiding of undesirable information about some functionary was proved, depended on the position of and attitude to the accused person. In some cases, especially at the beginning of the 1960s, during purges of national communists such facts were actively hunted for by the CC. For example, against the chief editor of the Party newspaper Cinna (Struggle) Pāvils Pizāns such accusations were used in combination with other reproaches, but in the case of the 1st secretary of Latvian Komsomol Vladislavs Ruskulis it was the lone reason for discharge. It is possible indeed that anonymous charges against national communists in some cases were not signals from below, but were inspired by the CC.

The use of one's official position for personal benefit was one of the main transgressions of nomenklatura immediately after the war on all levels - from county and district level to the government and the Central Committee. Even some high-level CC functionaries were discharged, expelled from the Party and even criminally persecuted for looting of furniture and other movable property. However, it seems that punishments were not severe, and general attitude of the CC in cases of abuse of power for personal benefit was rather mild if the accused person was considered 
to be effective in carrying out "the Party line". In the 1950s, when the selection of cadres became more orderly, cases of abuse of power became rarer.

One of constant charges were building of houses and dachas by functionaries making use of state resources and using their official position. In 1960, Khrushchev attempted to solve this problem by the campaign aim of which was to force the Party and state officials to give up their private houses and dachas under the threat of expelling from the Party. However, this campaign was short-lived, and in the 1970s dachas became very widespread among functionaries. Different abuses of regulations of building of houses and dachas on several occasions in the 1970s came under the scrutiny of the Party control institutions. In most cases it was the result of anonymous complaints sent to Moscow. In the 1970s, very widespread became also other forms of using of state resources for personal benefit, for example, building saunas and recreation centres which were used by all employees, but head managers often had special privileges in using them. Also big celebrations of jubilees of officials became usual.

Use of office privileges and state resources for personal benefit was a field in which changes in nomenklatura's corporate morality are most visible. The ideal type of an ascetic communist increasingly developed into an empty shell. Although Khrushchev tried to revive this ideal type, his attempt failed. In the 1970s, the moral standards of nomenklatura in Latvia, as well as in the Soviet Union at large, became more lax. The Party penalties served mostly as some kind of security valve, in order to preserve morals of the regime's administration from total collapse.

Family scandals, adultery, drinking and other offenses of the social life morality were not considered suitable for officials, but the Party control system was rather evasive as regards the control of officials' behaviour at private, if it was not scandalous and was not publicly exposed.

Indeed, the Party penalties had an important role in maintaining at least a certain level of ethical standards in the Latvian Communist Party and in the selection process of the nomenklatura. But the reaction to breaches of the Party ethics was rather reactive: authorities mostly responded to campaigns started by Moscow or to anonymous complaints. Problems were addressed on the case-to-case basis and in secrecy. In most cases only institutions and persons directly involved had full knowledge of the substance of offence. Such secrecy helped to maintain an image of power of the Party control and penalties' system, but its main aim was to create an impression that breaches of the Party morality were not common. 